\begin{tabular}{|l|c|c|c|r|}
\hline $\begin{array}{l}\text { Cuadernos de Investigación Geográfica } \\
\text { Geographical Research Letters }\end{array}$ & 2017 & N $^{\circ} 43(2)$ & pp. 591-628 & $\begin{array}{r}\text { ISSN 0211-6820 } \\
\text { eISSN 1697-9540 }\end{array}$ \\
\hline
\end{tabular}

DOI: http://doi.org/10.18172/cig.3265

(C) Universidad de La Rioja

\title{
THE LAST DEGLACIATION OF PERU AND BOLIVIA
}

\author{
B. MARK ${ }^{1 *}$, N. STANSELL ${ }^{2}$, G. ZEBALLOS ${ }^{1}$ \\ ${ }^{1}$ Department of Geography, Byrd Polar and Climate Research Center, \\ Ohio State University, Columbus, OH 43210, USA \\ ${ }^{2}$ Department of Geology and Environmental Geosciences, \\ Northern Illinois University, DeKalb, IL 60115, USA
}

ABSTRACT. The tropical Andes of Peru and Bolivia are important for preserving geomorphic evidence of multiple glaciations, allowing for refinements of chronology to aid in understanding climate dynamics at a key location between hemispheres. This review focuses on the deglaciation from Late-Pleistocene maximum positions near the global Last Glacial Maximum (LGM). We synthesize the results of the most recent published glacial geologic studies from 12 mountain ranges or regions within Peru and Bolivia where glacial moraines and drift are dated with terrestrial cosmogenic nuclides (TCN), as well as maximum and minimum limiting ages based on radiocarbon in proximal sediments. Special consideration is given to document paleoglacier valley localities with topographic information given the strong vertical mass balance sensitivity of tropical glaciers. Specific valley localities show variable and heterogeneous sequences ages and extensions of paleoglaciers, but conform to a generally cogent regional sequence revealed by more continuous lake sedimentary records. There are clear distributions of stratigraphically older and younger moraine ages that we group and discuss chronologically. The timing of the local LGM based on average TCN ages of moraine groups is $25.1 \mathrm{ka}$, but there are large uncertainties (up to $7 \mathrm{ka}$ ) making the relative timing with the global LGM elusive. There are a significant number of postLGM moraines that date to $18.9( \pm 0.5) \mathrm{ka}$. During the Oldest Dryas (18.0 to $14.6 \mathrm{ka})$, moraine boulders date to 16.1 ( \pm 1.1$) \mathrm{ka}$, suggesting that glaciers either experienced stillstands or readvances during this interval. The Antarctic Cold Reversal (ACR; 14.6 to $12.6 \mathrm{ka}$ ) is another phase of stillstanding or readvancing glaciers with moraine groups dating to $13.7( \pm 0.8) \mathrm{ka}$, followed by retreating ice margins through most of the Younger Dryas (YD; 12.9 to $11.8 \mathrm{ka})$. During the early Holocene, groups of moraines in multiple valleys date to 11.0 $( \pm 0.4) \mathrm{ka}$, marking a period when glaciers either readvanced or paused from the overall trend of deglaciation. The pattern of glacial variability during the Late Glacial after 14.6 ka appears to be more synchronous with periods of cooling in the southern high latitudes, and out-of-phase with the overall deglacial trend in the Northern Hemisphere. While insolation and $\mathrm{CO}_{2}$ forcing likely drove the 
general pattern of deglaciation in the southern tropical Andes, regional oceanatmospheric and hypsometric controls must have contributed to the full pattern of glacial variability.

\section{La Última Deglaciación en Perú y Bolivia}

RESUMEN. Los Andes Tropicales de Perú y Bolivia contienen evidencias geomorfológicas de múltiples glaciaciones $y$, mediante su datación, permiten comprender las dinámicas climáticas en sitios clave entre ambos hemisferios. La presente revisión se enfoca en la deglaciación a partir de la máxima extensión de los glaciares durante el Pleistoceno Tardío, próximo al Último Máximo Glaciar (LGM) global. Sintetizamos los resultados de los estudios geológicos y glaciológicos publicados en 12 cadenas montañosas entre Perú y Bolivia, donde se dataron las morrenas y sedimentos glaciares por medio de Nucleídos Cosmogénicos Terrestres (TCN), así como las edades máximas y mínimas de sedimentos cercanos por medio de radiocarbono. Dada la fuerte sensibilidad de los glaciares tropicales al balance de masa vertical, documentamos las localidades de los valles paleoglaciares que presentan información topográfica. Dichas localidades muestran secuencias de edad y extensiones de paleoglaciares heterogéneos y variables, pero conforman en general una secuencia regional coherente, como revelan los registros más continuos de sedimentos lacustres. Existen distribuciones claras de edades estratigráficamente anteriores y recientes que agrupamos y discutimos cronológicamente. La datación del LGM local basada en los promedios de edad por TCN de grupos de morrenas es de $25.1 \mathrm{ka}$, pero existen incertidumbres importantes (de hasta $7 \mathrm{ka}$ ) que dificultan la datación relativa con el LGM global. Existe un número significativo de morrenas posteriores al LGM que datan de 18.9 ( \pm 0.5$)$ ka. Durante el Dryas Antiguo (18.0 a $14.6 \mathrm{ka})$, los bloques morrénicos datan hasta 16.1 ( \pm 1.1$) \mathrm{ka}$, sugiriendo que los glaciares experimentaron tanto estabilidad como también nuevos avances durante este período. La Inversión del Frío Antártico (14.6 a $12.6 \mathrm{ka}$ ) es otra fase de estabilidad o avance de glaciares con grupos de morrenas que datan de 13.7 ( \pm 0.8$) \mathrm{ka}$, y que fue seguida por la retracción de los márgenes del hielo durante la mayor parte del Dryas Reciente (12.0 a $11.8 \mathrm{ka})$. Durante el Holoceno Temprano, grupos de morrenas en múltiples valles datan de 11.0 ( \pm 0.4$) k a$, marcando un período en que los glaciares detuvieron su retroceso o incluso volvieron a avanzar. Los patrones de variabilidad glaciar durante el Último Glaciar después de $\sim 14.6$ ka parecen más sincrónicos con períodos de enfriamiento de otras latitudes más al sur, y a su vez están desfasados con la tendencia general de deglaciación en el hemisferio norte. Mientras que la insolación e influencia de $\mathrm{CO}_{2}$ pudieron causar el patrón general de deglaciación en los Andes Tropicales del Sur, los factores hipsométricos y océano-atmosféricos regionales pudieron haber contribuido al patrón entero de variabilidad glaciar. 
Key words: Tropical Andes, Last Glacial Maximum, terrestrial cosmogenic nuclides, paleoglaciers, deglaciation.

Palabras Clave: Andes Tropicales, Último Máximo Glaciar, nucleídos cosmogénicos terrestres, paleoglaciares, deglaciación.

* Corresponding author: Bryan Mark, Department of Geography, Byrd Polar and Climate Research Center, Ohio State University, Columbus, OH 43210, USA. E-mail address: mark.9@osu.edu

\section{Introduction}

The Andes of Peru and Bolivia comprise numerous glaciated ranges containing most of Earth's extant tropical glaciers, along with multiple superimposed moraines that have provided glacial geologists appealing time-space markers to infer the extent and timing of late-Pleistocene to Holocene climate changes in the tropics (Clapperton, 1972; Hastenrath, 1985). Initial geomorphologic observations extending from the first decades of the twentieth century documented multiple glacial stages based on the superposition and relative weathering of inset moraines. Because these features appeared similarly in form and position (elevation, distance from headwall) in different regions, this was interpreted as evidence of synchronous advances along the Andes (Clapperton, 1983). A prominent twostage moraine sequence associated with the Last Glaciation was documented, and appeared well-correlated between different Peruvian ranges (Machare et al., 1990). Yet these early reviews featured very few absolute ages. In fact, this region featured only a single maximum limiting age for late-glacial moraines until the $21^{\text {st }}$ century (Mercer and Palacios, 1977). In context, this ample geomorphologic evidence needing further absolute ages inspired field research expeditions into the 1990's. Subsequent glacial geology and lake coring field work gathered radiocarbon dates to test the interhemispheric synchroneity of deglaciation (Seltzer, 1992), as well as the relative magnitude of low latitude climate sensitivity at the LGM (Hastenrath, 2009). Whether the deglaciation from last glacial maximum extents was interrupted by a late-glacial advance in the Andes coeval with the Younger Dryas was identified as a key question for resolving the extent to which the North Atlantic forces global climate (Clapperton, 1993; Rodbell, 2000; Rodbell and Seltzer, 2000), and remains unresolved. At the end of the twentieth century, long sedimentary records extracted from basins beyond the glacial limit provided key hydroclimatic proxies that revised earlier interpretations of a dry LGM, and suggested deglaciation was underway between $22 \mathrm{ka}$ and 19.5 ka BP, thousands of years prior to the Northern Hemisphere (Seltzer et al., 2000; Baker et al., 2001a, 2001b; Seltzer et al., 2002).

In the most recent decades, the chronology of tropical Andean deglaciation has been further refined with more widespread acquisition of terrestrial cosmogenic radio nuclide (TCN) exposure ages on moraines, as well as additional radiocarbon dates. Research has been motivated to better understand the extent, timing and dynamics of 
low-latitude glaciers in response to both global and local forcing, considering large gradients in precipitation related to prevailing winds and topography. Major questions of global synchroneity of glaciation continue to be actively explored, and as the location with most remaining tropical glaciers, the tropical Andes of Peru and Bolivia are important in efforts to systematically compile databases of glacier activity as a proxy for climate in paleoclimate modeling and intercomparison projects (i.e. Mark et al., 2005). TCN-based chronologies of moraines in Peru and Bolivia substantiated the previously hypothesized local maximum extent as occurring early during the last glacial cycle, with a more diminutive extension during the global LGM (Smith et al., 2005). However, methodological differences in the application of TCN techniques (sampling, production rate choice, age calculation, and interpretation) have resulted in different interpretations of glaciation timing and paleoclimate forcing (Zech et al., 2008; Glasser et al., 2009; Smith and Rodbell, 2010). Reviews have assimilated the basic understanding of the age of glacial geomorphic features in various localities, taking care to tabulate all relevant information to enable fair comparisons of TCN methodology (e.g. Rodbell et al., 2009; Smith et al., 2008), and provided georeferenced maps of moraine features (La Frenierre et al., 2011). Other syntheses have used derivatives like equilibrium line altitudes (ELAs) and snowlines to quantify the extent and spatial variability of glacier mass fluctuations in response to climate over time (Rodbell, 1992; Seltzer, 1992; Mark et al., 2005; Ramage et al., 2005). Given the discontinuous nature of the glacier moraine record (i.e. Seltzer, 1990), other work has used lake sediments (Rodbell et al., 2008; Rodbell et al., 2009) to document changes in glacier activity within catchments. Recent summaries have refocused particularly on the deglaciation timing as a means to test hypotheses related to understanding global climate forcing, i.e. synchronous glacier responses might indicate changes in atmospheric carbon dioxide as a global forcing (He et al., 2013; Shakun et al., 2015a).

Our goal in this review is to compile and synthesize the data available from papers published subsequent to the compilations of glacial geology that have tabulated (Smith et al., 2008; Rodbell et al., 2009) and ArcGIS mapped (La Frenierre et al., 2011) glacial geology in Peru and Bolivia from the Late Pleistocene. We will summarize and document localities where combinations of moraine chronology and lake sedimentary records exist. By focusing on deglaciation, we will restrict our review to the latePleistocene to Holocene transition. We will not review Holocene to modern changes. We revisit specific localities to identify the extent of evident glacier changes in space and time, documenting relevant topographic dimensions (headwall and terminal elevations, aspect) and providing an overview map to identify the specific locations with key attribute information. This specific contextual information will allow for more effective review by facilitating a 3D visualization of sites that can add insights to local controls, and hopefully guide subsequent research. We will focus primarily on updating reviewed information based on new moraine ages that have been developed since 2009, but will also reference previously published ages derived from other geomorphologic features (lakes sediments, bedrock exposures) that serve as time - position markers for glacial extensions during the last deglaciation.

Since cosmogenic radionuclide exposure age dating is the current state of the art method used to date moraines, it is important to acknowledge the variations in production 
rate calculations that can impact ages and uncertainties. Our review will follow practices established by others (Shakun et al., 2015a) to tabulate individual data on specific samples and enable a standardized procedure of computing shielding and weathering. We will draw a synthesis around known climatic events from other regions to assess how well this tropical region reflects global forcing.

\section{Setting}

The glaciated Andes of Peru and Bolivia span the latitudes of $\sim 6^{\circ} \mathrm{S}$ to $23^{\circ} \mathrm{S}$, and encompass a range of geology and climates as large-scale circulation features intersect various topographic forms. A general progression from more humid to more arid conditions is encountered along $\mathrm{N}$ to $\mathrm{S}$ and $\mathrm{E}$ to $\mathrm{W}$ trajectories across the Andes in this region of Peru and Bolivia. We direct attention to previous reviews for more thorough presentations of regional climate (Clapperton, 1983; Seltzer, 1990; Rodbell et al., 2009). Here we summarize some features relating to the orography and climate dynamics that sustain glaciers at these latitudes.

The geology of these tropical Andean ranges is complex, resulting from collisional tectonics of mixed crustal lithology. The physiography of the Andes varies from N-S through Peru and Bolivia, assuming a series of parallel ridges getting successively wider, and ending in Southern Bolivia amidst the Altiplano proper. The uplift history is also complicated in detail but has an overall framework that is recognized, featuring continual movement of orogenic mass into the cryosphere (Smith et al., 2008), and with no more than $50 \%$ of the elevation attained by $10 \mathrm{Ma}$ (Gregory-Wodzicki, 2000; Insel et $a l ., 2012)$. This uplift history has long imprinted strongly on the resulting precipitation patterns of the region, with a distinctive rain shadow in place by $15 \mathrm{Ma}$, reinforced by subsequent orographic development (Hartley, 2003). Exposures of glaciofluvial deposits below lavas radiogenically-dated to over 3 Ma near La Paz, Bolivia (Clapperton, 1979) confirm that the Andes were high enough in this region to have been glaciated further back into the Pleistocene, although outcropping of such evidence is rare. This makes the region a likely setting for having the most detailed record of tropical glaciation through time anywhere on Earth (Hall et al., 2009).

The climate of the tropical Andes is typical of low latitudes, where the diurnal temperature range is greater than the annual range. Precipitation is derived mostly from Atlantic Ocean moisture that is transported to the Andes via the easterlies (Garreaud et al., 2009). Seasonal rainfall variability in the tropical Andes is linked to the position of the Intertropical Convergence Zone (ITCZ) over the Pacific and Atlantic Oceans, and by the strength of the South American Summer Monsoon (SASM) over the Amazon Basin (Zhou and Lau, 1998; Maslin and Burns, 2000; Maslin et al., 2011; Vuille et al., 2012). Inter-annual and multi-decadal rainfall patterns and temperature fluctuations over South America are affected by variability in mean-state conditions in the Atlantic and Pacific Oceans (Johnson, 1976; Nobre and Srukla, 1996; Henderson et al., 1999; Vuille et al., 2000; Bradley et al., 2003; Vuille and Werner, 2005). For example, the warm phase of the El Niño Southern Oscillation (ENSO) typically produces higher wet season rainfall amounts at low elevations along the Pacific coast of the central Andes, and the 
opposite during cold phases (Coelho et al., 2002). At altitude, glaciers are affected by ENSO through large-scale circulation dynamics and zonal flow anomalies in the upper troposphere that affect snowfall (Vuille et al., 2008a). Although the relationship varies geographically and breaks down during certain years, El Niño events generally cause warm and dry conditions, whereas La Niña events are cold and wet in alpine regions of the southern tropical Andes (Vuille et al., 2008b). In addition, precipitation amounts are affected by positive sea-level pressure anomalies in the North Atlantic Ocean, as these usually result in a displacement of the ITCZ and a shift in the strength of the SASM (Chiessi et al., 2009). Cloud cover data from satellite imagery, and relative humidity values from station data also indicate a seasonal pattern, with generally higher levels during the wet season (Fairman, 2006).

Aspect and the orientation of glaciers are largely controlled by the structural trend of the Andes, and also reflect regional gradients in precipitation and solar radiation (Hastenrath, 2009). The NW-SE trend of the mountain ranges in central Peru generally explains the distribution of glaciers (Kaser and Georges, 1997). While precipitation moisture originates from easterly winds, the local geologic structure of the central Andes and resulting diurnal shading favors the development of more and larger glaciers in SW facing valleys (Kaser and Georges, 1997; Mark and Seltzer, 2005).

The mass balance of glaciers in the tropical Andes responds to both temperature and precipitation changes, but is critically limited by elevation given a steep vertical mass balance gradient. Glaciers in the tropics are distinct from those in higher latitudes because temperatures are fairly consistent throughout the year given constant radiation regime, while distinct seasonality of precipitation allows for accumulation and ablation to occur simultaneously (tropical glacier dynamics are comprehensively discussed by Kaser and Osmaston, 2002). The freezing height of precipitation and relative amount of snowfall are determinative for glacier mass balance. Ablation is more intensely focused below the equilibrium line elevation (ELA) and occurs all year round, while accumulation is restricted seasonally to regions above elevations dividing snow and rain, and this tends to persist at a constant altitude throughout the year (Vuille et al., 2008a). Tropical glaciers have high mass accumulation area ratios (Rodbell et al., 2009), and are thus fundamentally constrained by landscape hypsometry (area to elevation) and precipitation.

From a glaciological perspective, the central Andes are intermediate between the inner and outer tropics, with precipitation and humidity being seasonal, yet high enough to limit substantial ice loss to sublimation (Kaser and Osmaston, 2002). The dominant mode of ablation in these regions is melting, and the ELA of glaciers mimics the local freezing level height (or $0^{\circ} \mathrm{C}$ isotherm). Modern temperature values and radiosonde observations indicate that ELA's in the central Andes have risen by at least $70 \mathrm{~m}$ since A.D. 1962, as a consequence of warming temperatures (Mark and Seltzer, 2005). At the same time, precipitation has decreased, accelerating the rate of recent glacial retreat (Vuille et al., 2008a). Strong gradients in precipitation exist across the Andes in this region, with wetter conditions to the east given predominant precipitation sources of the easterly trade winds. There is also progressively greater aridity encountered toward the south over the Altiplano of Bolivia. These geographic patterns have long been recognized 
for imprinting spatial variations in glacier-climate sensitivity by influencing the snowline (Seltzer, 1990), so that the reconstructions of previous glacier ELAs also reflects strong topography-moderated gradients (Seltzer, 1993).

\section{Material and methods}

In this review, we focus on sites that have published data from specific valleys (localities) with radiometrically-dated glacial geomorphologic evidence to provide absolute chronology for deglaciation. We emphasize where dated moraines are coupled to additional sedimentary records to provide more continuous information. We identify 12 sites that are listed in subsections of Section 4 below, and are highlighted by numbered boxes in Fig. 1. Each site contains different specific glacial features with absolute ages, and we have clustered them by mountain range or relative regional proximity.

The basic unit of analysis for glacier reconstruction is the paleoglacier valley locality (i.e. Mark et al., 2005), since the moraines and other glacier features were ultimately emplaced in a valley context featuring a maximum elevation constraining the accumulation zone. Establishing ages for glacial events involves sampling erratics on moraines, detailing information relevant for TCN age calculations (e.g. Licciardi et al., 2009), and seeking sedimentary deposits proximal to moraines to recover maximum or minimum limiting ages with radiocarbon (i.e. Seltzer, 1990).

We strive to tabulate and evaluate the specific geomorphological and topographical contexts for paleoglacier mass changes in each locality (Table 1). The local topographic context plays a role in how much the deglaciation proceeds and how fast. We use a commonly available topographic mapping interface (Google Earth, hereafter GE) to locate published localities with consistent geographic coordinates and variables that constrain the paleoglacier including valley aspect, summit or headwall elevation, and terminal moraine elevation (if discernible). This detail is relevant in efforts to reconstruct paleo ELA's, or conduct modeling to reconstruct paleoglaciers. We distribute the locality information to allow more common evaluations of local factors that modify climatic forcing of deglaciation, and also guide future work by allowing inspection of nearby features that might provide additional detail. We have compiled previously tabulated moraine information (La Frenierre et al., 2011) with additional features (Supplementary GE files are available upon request).

Here we use data for tropical Andean cosmogenic ages from the recent synthesis by Shakun et al. (2015a), which applies the most up to date and comprehensive production rate calibration and scaling methods. In the case of Illimani (Smith et al., 2011), ages were not available in the Shakun et al.(2015a) composite, and we recalculated with the Quelccaya ${ }^{10} \mathrm{Be}$ production rate calibration (Kelly et al., 2015), and the CRONUS-Earth calculator version 2.3 with the time-invariant 'St' scaling method of Stone (2000) following Lal (1991). Newly published data from the Cordillera Carabaya (Bromley et al.,2016) and Nevado Huaguruncho (Stansell et al., 2015) were calculated by the authors using the Quelccaya production rates. We also use radiocarbon ages in the compilation by Rodbell et al. (2009), combined with more recent publications for the Cordillera Huayhuash (Hall et al., 2009), Cordillera Raura (Stansell et al., 2013), and Nevado Huaguruncho (Stansell et al., 2015) (Table 2). 


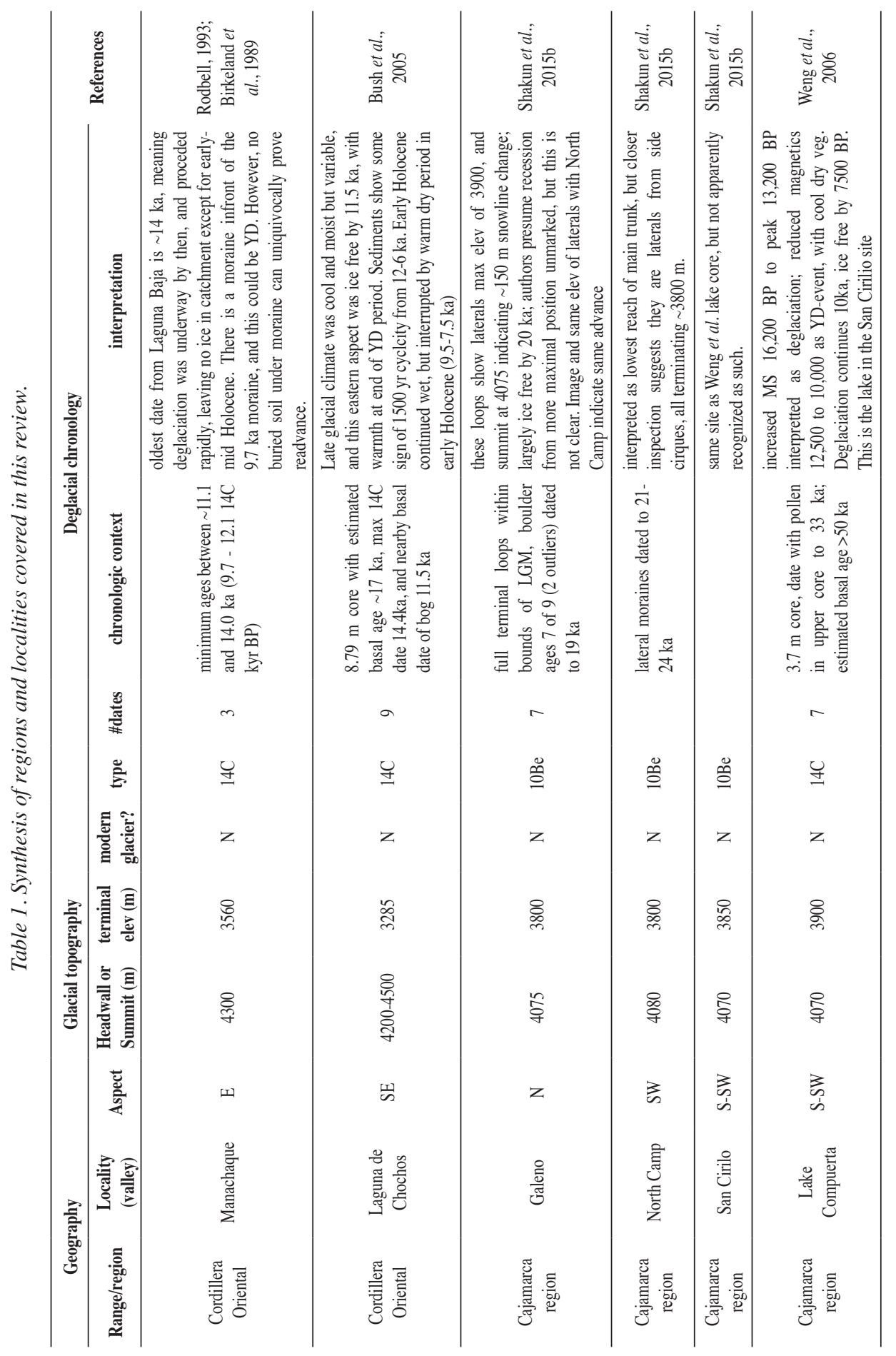




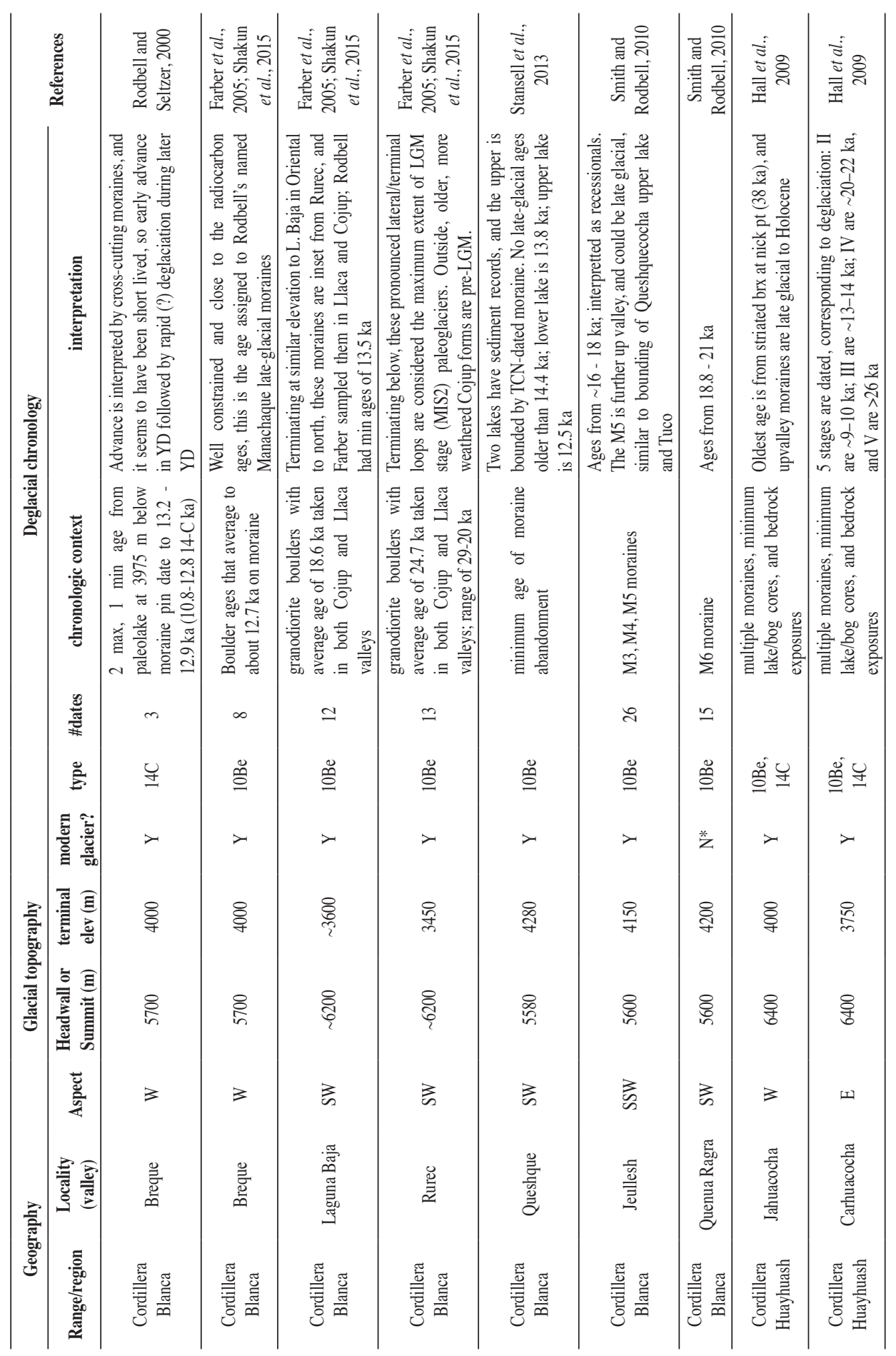




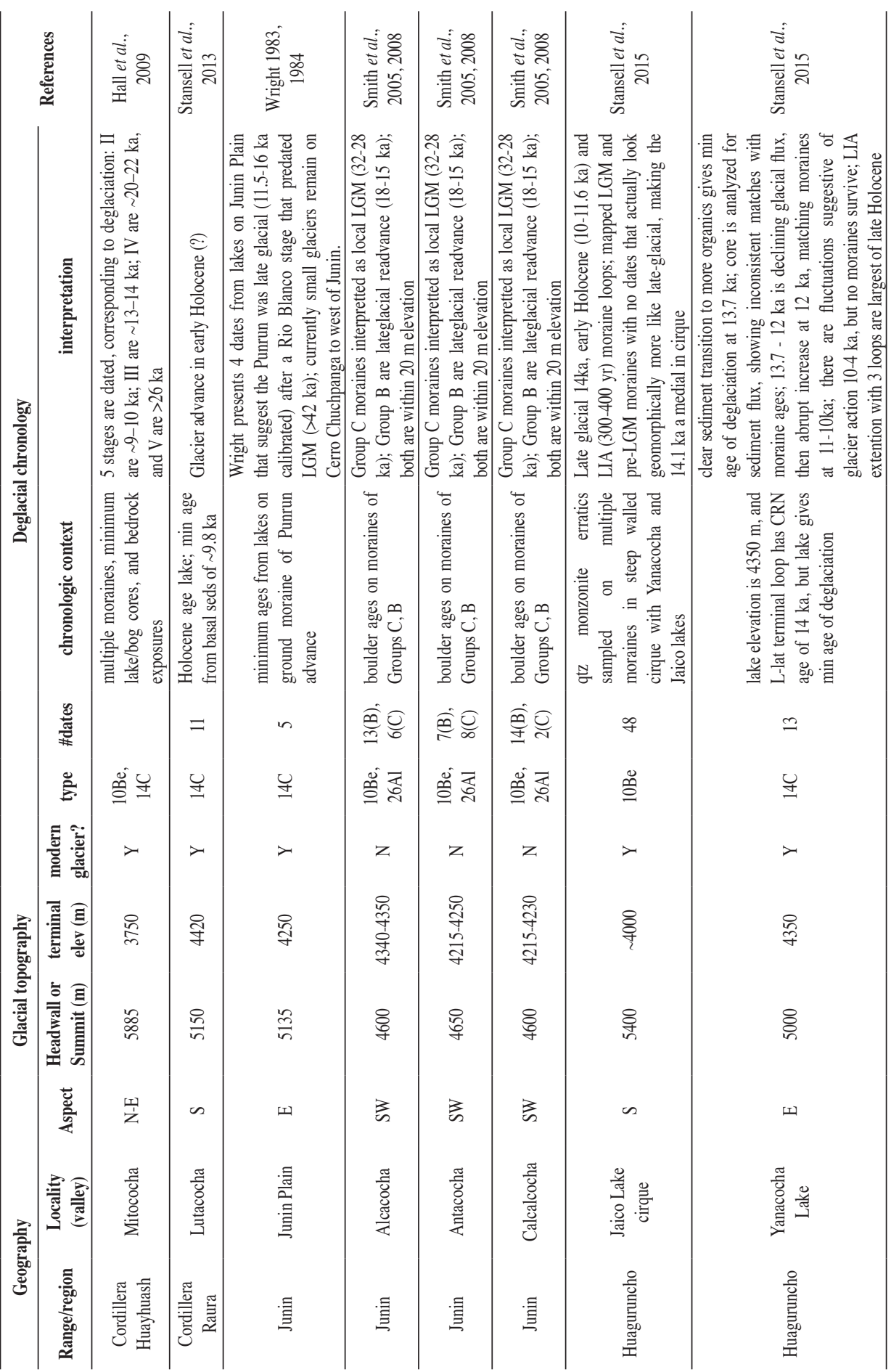




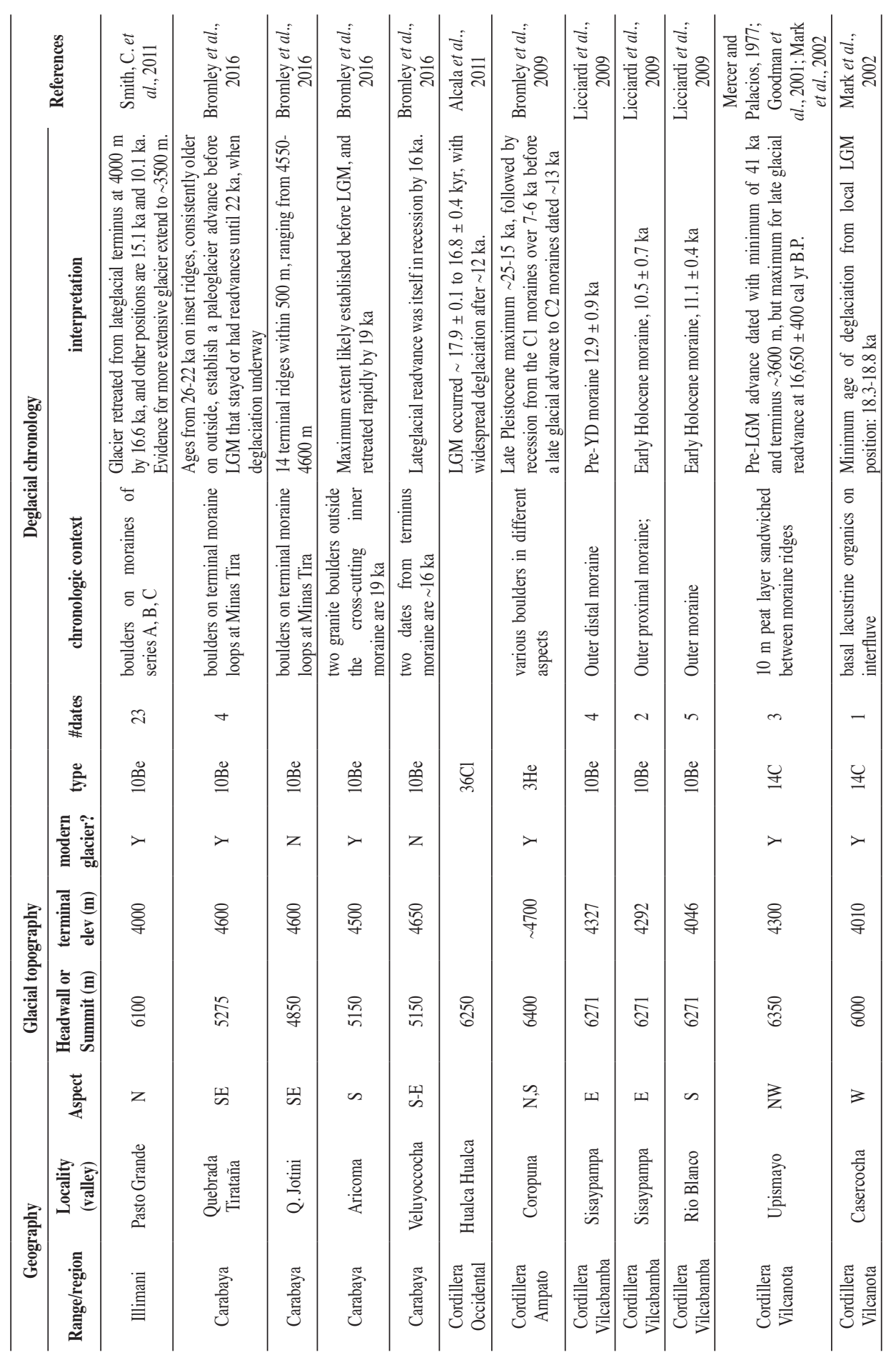




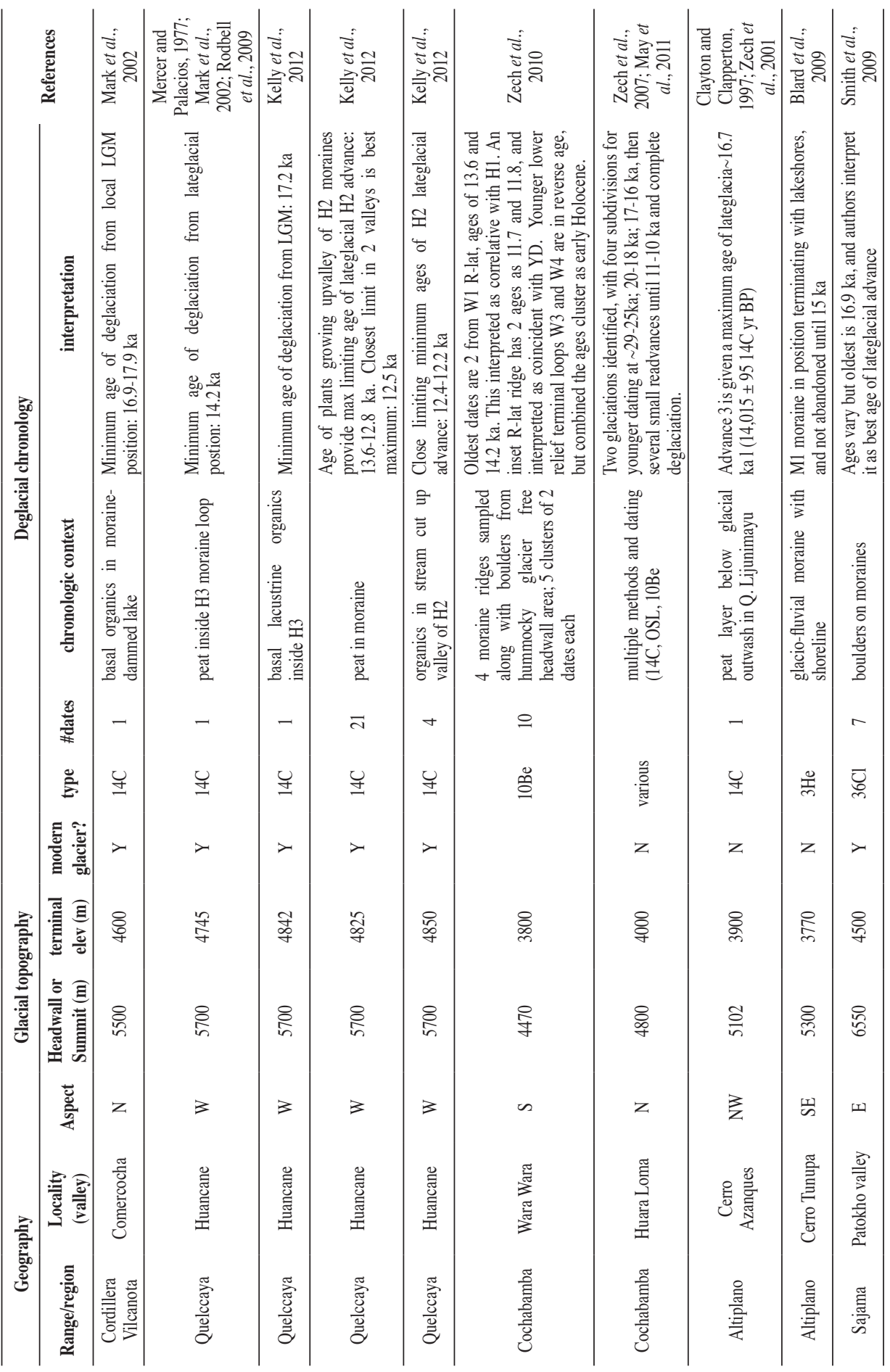




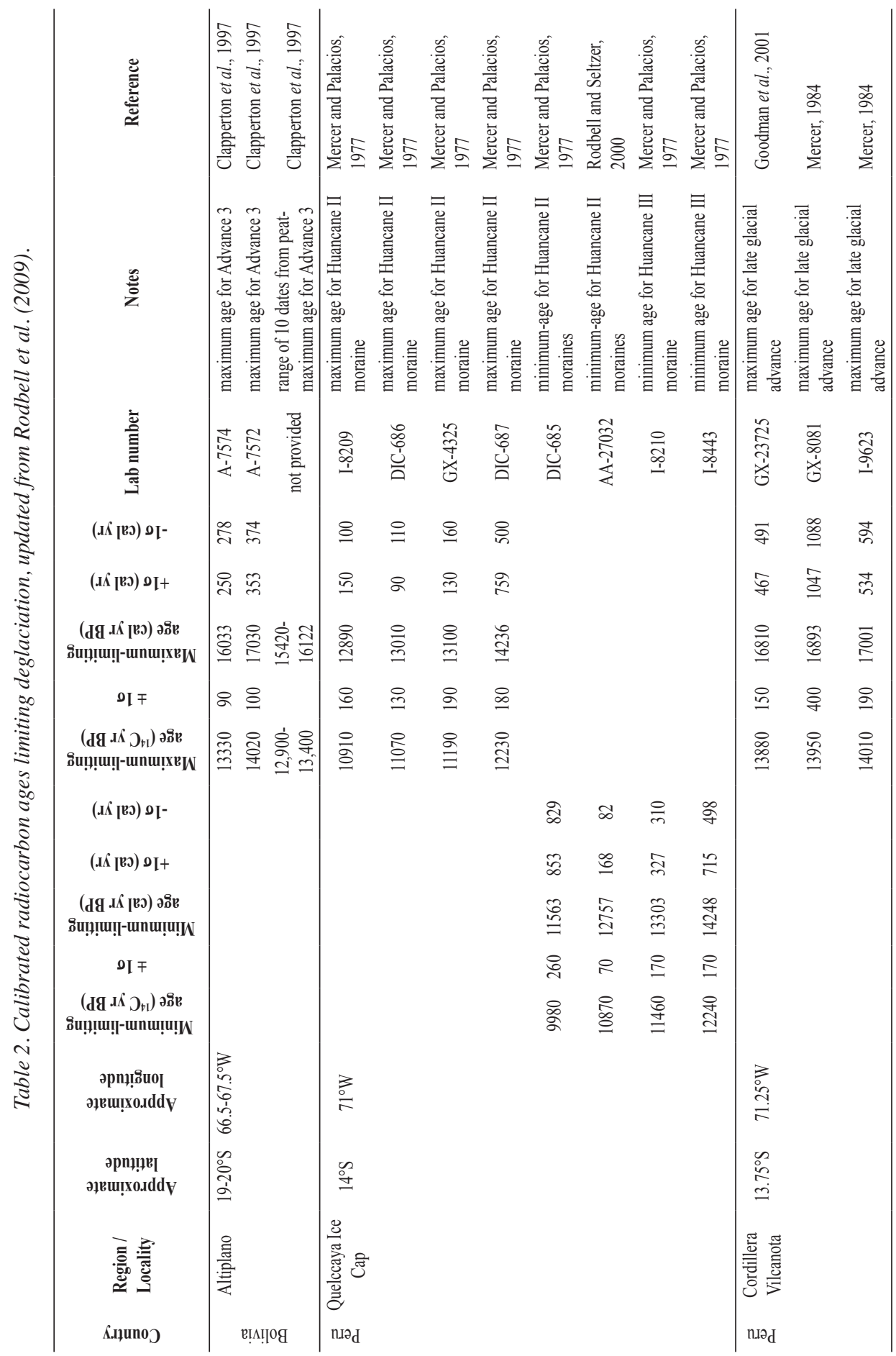




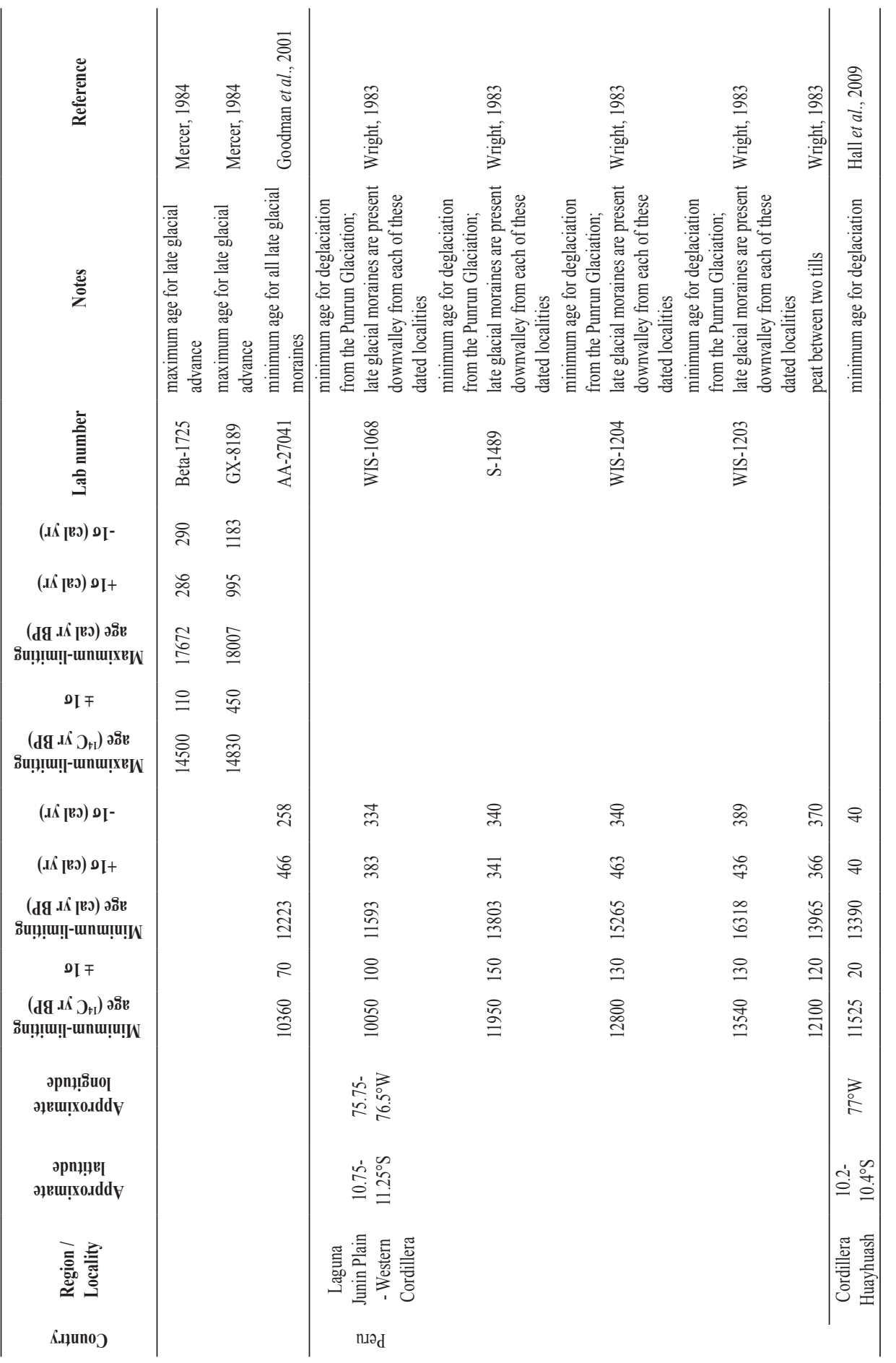




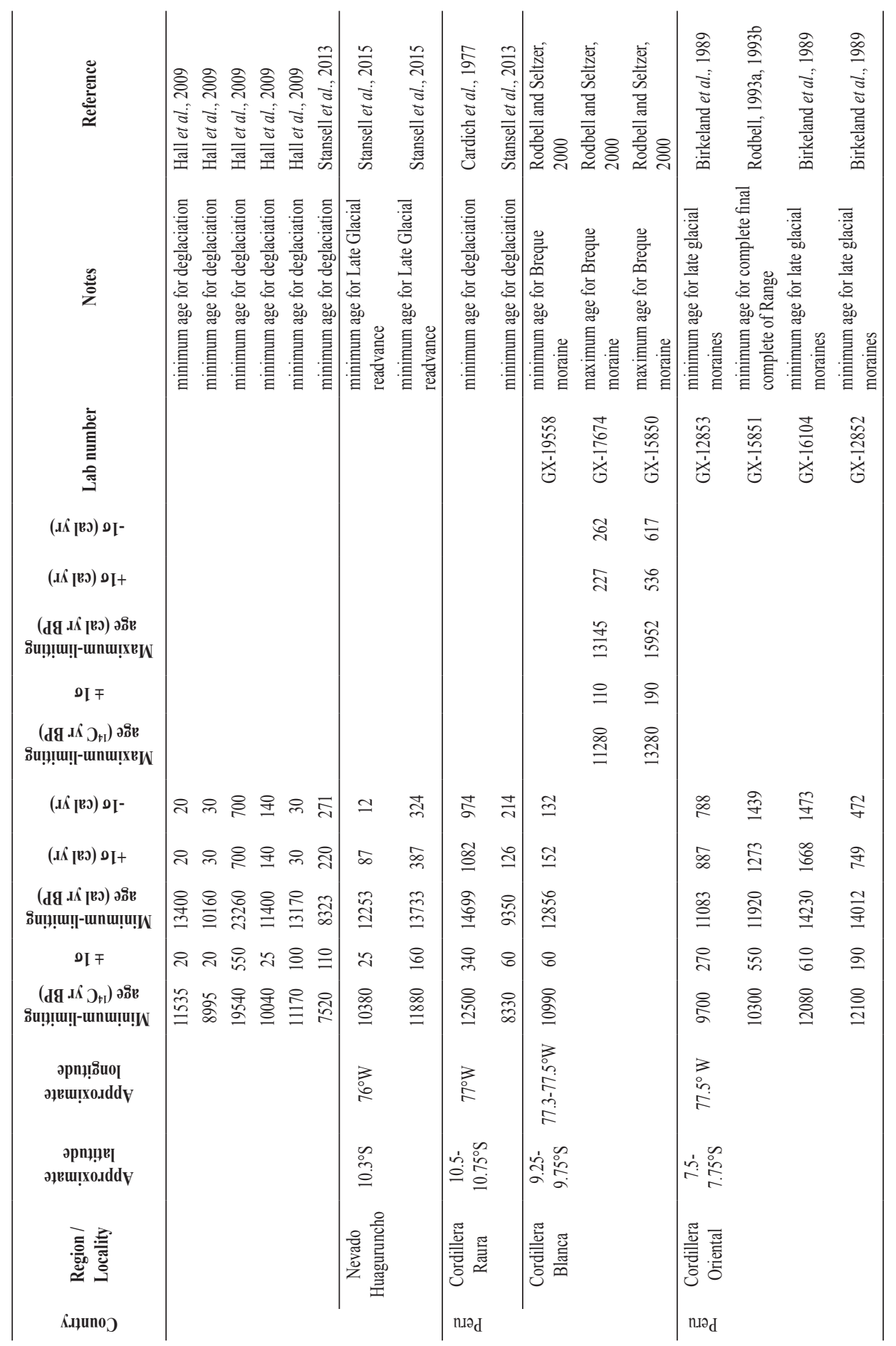




\section{Review of sites with chronologic data}

\subsection{Cordillera Oriental and Cajamarca Region}

Three radiocarbon dates from the eastward-draining Manachaque Valley of the Cordillera Central provided the first constraints on the deglacial history of the region (Birkeland et al., 1989; Rodbell, 1993b). The valley has headwall elevations reaching $\sim 4300 \mathrm{~m}$, and are no longer glacierized. Numerous well-preserved moraines are present in the $13 \mathrm{~km}$ glaciated portion of the valley before the low-gradient U-shape valley form changes to $\mathrm{V}$-shaped. The moraines are prominent forms, but are not distinctively different in age, and have similarly developed soil profiles. The dates were obtained from successively higher positions, and provide minimum-limiting radiocarbon ages between $\sim 14.0$ and $11.1 \mathrm{ka}\left(12.1-9.7{ }^{14} \mathrm{C} \mathrm{kyr} \mathrm{BP}\right)$ for late-glacial moraines in this range.

The furthest down valley date comes from the base of a sediment core extracted from Laguna Baja, providing the oldest minimum-limiting age of $14 \mathrm{kyr} \mathrm{BP}\left(12.1{ }^{14} \mathrm{C} \mathrm{kyr} \mathrm{BP}\right)$. Notably, there was no evidence found for this being a readvanced ice position, despite extensive trench digging at the moraine base looking for buried organic material to date. The next youngest moraine is $\sim 3 \mathrm{~km}$ upvalley and the basal age of a bog impounded by the moraine is $11 \mathrm{kyr} \mathrm{BP}\left(9700{ }^{14} \mathrm{C}\right.$ yr BP $)$. This position is equivalent to a $50 \%$ reduction in glacier ice cover from the maximum. A final date of $6450 \mathrm{yr} \mathrm{BP}$ comes from organic material over till behind the highest moraine, marking a position with $<10 \%$ of the maximum ice extent.

Hansen and Rodbell (1995) provide pollen data from Laguna Baja, and interpret oscillations in late glacial vegetation and climate. The setting was already warm and moist given open mixed montane forest pollen at the base of the core. There is suggestion of a cooler/more arid interval based on expanded paramo vegetation between 11.6 and $10 \mathrm{kyr}$ BP. The progression is apparently rapid warming toward the Holocene, with both temperature and precipitation increasing by about $10 \mathrm{ka}$, resulting in wet montane forest displacing paramo. Additionally, Laguna de Chochos $(3285 \mathrm{~m})$ on the eastern side of the divide below was cored and provides a $\sim 17 \mathrm{kyr}$ record showing wet, cool and variable climate during 17-11.5 ka deglaciation (Bush et al., 2005). There is no evidence of glacier readvance at the YD, but a radiocarbon date from a bog above the lake shows the cirque was ice-free by $11.5 \mathrm{ka}$ when conditions warmed at the end of the YD period.

A cluster of recently published TCN dates from moraines located in the Northern Peruvian Andes, near Cajamarca, provide the most northerly situated localities (Shakun et al., 2015b). They are currently unglacierized, and the maximum elevations in the catchment at $<4100 \mathrm{~m}$ constrain the extent of ice cover. The Galeno moraines are NE aspect and show complete inset lateral/terminal loops reaching to $3800 \mathrm{~m}$ only $150 \mathrm{~m}$ shy of the summit, with maximum lateral moraine elevations of $3900 \mathrm{~m}$ and an average age of $19 \mathrm{ka}$ based on seven of nine ( 2 outliers) TCN sampled boulders. The paleoglacier drains to a larger valley but no lower moraines were identified.

The North Camp moraines comprise two lateral ridges that are described by Shakun et al. (2015b) as left and right laterals of a single paleoglacier with SW aspect, sharing a 
common headwall elevation with Galeno moraines on the opposite side. The average TCN dates of $23.7 \mathrm{ka}$ are slightly earlier than the global LGM. On the basis of this interpretation, the authors presume the Galeno to be recessional positions for a larger extent. Nevertheless, it should be noted that a closer inspection of the topographic context suggests an alternative interpretation that these are not laterals of the main valley, but actually laterals from separate smaller cirque glaciers entering the main trunk. As such, they would share the same terminal elevation as Galeno. Thus there is not convincing evidence that the glaciers extended further than $3850 \mathrm{~m}$ during this stage. The glaciated geomorphology of the U-shaped valleys and apparent but undated moraines that appear lower (to 3500-3300 m termini) do suggest there were older, more extensive advances, but no dates yet exist.

The San Cirilo site is located just over $30 \mathrm{~km}$ to the WNW of the North Camp moraines, and comprises multiple discontinuous moraine ridges of SW aspect and kettle lakes around summit crags $\sim 4070 \mathrm{~m}$, interpreted to be a site of ice wastage on a broad shallow divide. There are other similar features evident on the landscape to the north. Muted but discernible terminal loops in nearby valleys end at $3850 \mathrm{~m}$. The average age of the 8 boulder and 1 bedrock samples is $21.2 \pm 0.8 \mathrm{ka}$ ( 3 additional were excluded as outliers for being $>10 \mathrm{ka}$ older). The elevation profile for this site is very different than the others, but the headwall is similarly $\sim 4000 \mathrm{~m}$.

All told, these data are best interpreted as signifying that an advance of unknown initiation ended at a similar age to the LGM, 20 ka, leaving ice free conditions for areas with $<4100 \mathrm{~m}$ headwalls/summits. The downvalley geomorphology suggests there were older, more extensive glaciers, but none younger. This constrains the extent of Holocene climate in the region by snowline/ELA elevations that were within $\sim 1 \mathrm{~km}$ of modern.

Although hitherto not recognized as being from the same location, another study reports on a 33,000 year lake sediment record recovered from Lake Compuerta, situated amidst the San Cirilo site at $3950 \mathrm{~m}$ (Weng et al., 2006). The authors use pollen, charcoal, MS and bulk density to make a paleoecological reconstruction of the region, but incorrectly recorded the position of the lake in their paper. Based on the satellite image from the published location figure, this lake is evidently one of the lakes left behind from the collapsed ice cap referenced by Shakun et al. (2015b). Significantly, this repositioning also revises the elevation estimate published for surrounding summits to the headwall elevation mentioned previously for San Cirilo of $<4100 \mathrm{~m}$.

The Lake Compuerta core shows a sedimentation hiatus from $~ 30$ ka until $16.2 \mathrm{ka}$. Conceivably, this could be consistent with an episode of glacier advance that initiated before the LGM, but endured throughout, causing ice to override the lake, and end up depositing the hummocky moraines that have erratics dated by TCN at 21-23 ka (Shakun et al., 2015b), interpreted as the minimum ages of deglaciation. Weng et al. interpret high sedimentation rate and increased magnetic susceptibility as glacial outwash intensity related to glacier recession, not advance. They note a reduction in MS from 12.5 to $10 \mathrm{ka}$, and see vegetation shifts reflecting cool, dry conditions and interpret this to evidence of a YD chron advance. The subsequent deglaciation resumes at $10 \mathrm{ka}$ and is relatively quick, with complete loss of ice by $7.5 \mathrm{ka}$. 


\subsection{Cordillera Blanca}

Site of the world's most glacierized tropical mountains currently, with $>25$ summits over $6000 \mathrm{~m}$, this range also features multiple stages of prominent moraines that indicate much more extensive glaciers in the past. Equilibrium-line-altitude (ELA) reconstructions indicate that ELAs during the last glacial maximum (LGM: marine isotope stage 2) were c. $4300 \mathrm{~m}$ in the Cordillera Blanca, c. $39003600 \mathrm{~m}$ on the west side of the Cordillera Oriental, and c. $3200 \mathrm{~m}$ on the east (Amazon Basin) side of the Cordillera Oriental. Comparison with estimated modern ELAs and glaciation thresholds indicate that ELA depression ranged from c. $700 \mathrm{~m}$ in the Cordillera Blanca to c. $1200 \mathrm{~m}$ on the east side of the Cordillera Oriental. This augments data from many mountain ranges in middle- and low- latitude regions that indicate that ELAs during the LGM were depressed by c. $1000 \mathrm{~m}$. Published palynological evidence for drier conditions during the LGM in the tropical Andes suggests that ELA depression of this amount involved a temperature reduction (>5-6-degrees-C) that greatly exceeded the tropical sea surface temperature depression estimates of CLIMAP ( $<2$ - degrees-C) (Mark et al., 2005). The west to east increase in ELA depression during the LGM indicates that the steep modern precipitation gradients may have been even steeper during the LGM.

Initial descriptions of the moraines relied primarily upon superposition and similarity of form between valleys to cluster into four relative age groups (Clapperton, 1981). Rodbell provided more substantive chronological classification based on relative weathering features and minimum radiocarbon dates, identifying two moraine stages, Rurec and Laguna Baja, with ages likely close to (pre and post) LGM (Rodbell, 1993a). Subsequent TCN dates based on samples from the SW aspect Cojup and Llaca Valleys, show a two stages within the last glacial with average ages of $24.7 \mathrm{ka}$ (Rurec) and $18.6 \mathrm{ka}$ (Laguna Baja) (Faber et al., 2005). In the Rurec Valley, closely bounded late-glacial Manachaque moraine at the Breque site was confirmed as $12.7 \mathrm{ka}$, indicating a readvance at this time, followed by relatively rapid recession.

This pattern conforms to a general pattern seen by integrating the TCN moraine ages throughout the region with a stacked, composite record of lake sediments (Rodbell et al., 2008) that indicates a decline in clastic sediment flux that began $\sim 20 \mathrm{ka}$ appearing to mark the onset of deglaciation, at least one millennium prior to significant warming in high latitude regions. The interval between 20 and $18 \mathrm{ka}$ was marked by near-Holocene levels of clastic sediment flux, and appears to have been an interval of much reduced ice extent. An abrupt increase in clastic sediment flux $18 \mathrm{ka}$ heralded the onset of an interval of expanded ice cover that lasted until $\sim 14 \mathrm{ka}$. Clastic sediment flux declined thereafter to reach the lowest levels of the entire length of record during the early-middle Holocene.

The oldest post-LGM moraines from the Cordillera Blanca that have been dated by TCN are located in the Juellesh and Tuco valleys. The M6 moraine presented by Smith and Rodbell (2010) has inner and outer loops that date to $\sim 18.8 \pm 2.0 \mathrm{ka}$ and $\sim 18.7 \pm$ $1.6 \mathrm{ka}$, respectively. Glasser presented similar ages on an outer lateral moraine in the Tuco valley at $\sim 18.3 \pm 1.4 \mathrm{ka}$. The M4 inner lateral moraine dates to $\sim 18.8 \pm 2.3 \mathrm{ka}$, and Glasser et al. (2009) similar ages on that moraine from $\sim 17.9 \pm 0.9 \mathrm{ka}$. 
The Late Glacial TCN ages from Queshque (Stansell et al., 2017) are comparable to the Glasser et al. (2009) and Smith and Rodbell (2010) Late Glacial and Holocene TCN ages from the nearby Jeullesh valley. The available The M5 moraine (15.7 $\pm 1.8 \mathrm{ka})$ has been interpreted by Smith and Rodbell (2010) as recessional, or possibly a stillstand feature. Similar ages have been presented for the middle Juellesh valley moraine (ca. $14.1 \pm 0.1 \mathrm{ka}$ ) by Glasser et al. (2009). The M3 left-lateral moraine of Smith and Rodbell (2010) date to ca. $14.4 \pm 0.5 \mathrm{ka}$, and could actually be from the M5 ice limit. The M5 ice limit is thus likely associated with the right-lateral moraine below Lower Queshquecocha (ca. $13.8 \pm 0.4 \mathrm{ka}$ ).

Ice core records from Nevado Huascarán indicate that periods of cooling at the onset of the ACR, and just prior to the start of the YD, punctuated an overall trend of warming conditions during the Late Glacial. The Breque site in the Cordillera Blanca provides a close limiting age for glacier advance between 13.2 and $12.9 \mathrm{ka}$ (11.28 and $10.99{ }^{14} \mathrm{C}$ ka BP), with rapid recession afterwards. The age for the Breque moraine is supported by $10 \mathrm{Be}$ ages that range from $13.2 \pm 0.5$ to $10.4 \pm 0.4 \mathrm{ka}$ (Farber et al., 2005). Notably, there is a lack of TCN ages within the YD for the Jeullesh and Queshque valleys, which is consistent with evidence of retreating ice margins based on the closely dated Manachaque moraine in the nearby Breque valley (Rodbell and Seltzer, 2000).

Evidence for early Holocene readvances or stillstands in the Cordillera Blanca is recorded in TCN ages and supported by the lake sediment data from the Queshque valley (Stansell et al., 2017). End moraines enclosing Upper Queshquecocha were constructed ca. $10.8 \mathrm{ka}$, and then ice retreated sometime after ca. $10.4 \mathrm{ka}$. These moraine ages generally correspond to the timing of increased clastic sediment flux in Lower Queshquecocha from ca. 10.4 to $9.8 \mathrm{ka}$. Another early Holocene end moraine $180 \mathrm{~m}$ up-valley from the upper lake formed sometime prior to ca. $9.4 \pm 0.3 \mathrm{ka}$. Similarly, a recessional moraine or stillstand feature upvalley from the M5 position in the Jeullesh valley dates to ca. 11.6 \pm $0.4 \mathrm{ka}$ (Glasser et al., 2009), which is similar in age to the early Holocene end moraines that are between Upper Queshquecocha and Lower Queshquecocha (10.9 \pm 0.1 and 10.5 $\pm 0.4 \mathrm{ka})$.

\subsection{Cordilleras Huayhuash and Raura}

South and east of the Cordillera Blanca, the Cordilleras Huayhuash $\left(10^{\circ} 16^{\prime} \mathrm{S}\right)$ and Raura $\left(10^{\circ} 28^{\prime} \mathrm{S}\right)$ are currently glacierized, with highest summits over $6500 \mathrm{~m}$ (Yerupaja) in the Huayhuash, and just below $5700 \mathrm{~m}$ in the Raura. The summits are steep, NW to SE trending ridges, with steeper and more incised valleys on the west. The most comprehensive dataset for the Cordillera Huayhuash, to date, was presented by Hall et al. (2009). Here they include both basal radiocarbon ages from lake sediment records and TCN ages on moraine boulders. The revised TCN ages that represent various stages of deglaciation are centered on $\sim 17.8$ to $16.5 \mathrm{ka}, 14.9$ to $14.3 \mathrm{ka}$, and 11.6 to $9.0 \mathrm{ka}$. Paleoglacier margins below Lake Jahuacocha on the western side of the Huayhuash were also dated to the late glacial stage. While the moraine that impounds Jahuacocha has revised TCN ages ranging from $\sim 12.2 \pm 0.5$ to $8.7 \pm 0.4 \mathrm{ka}$, 
the basal lake sediments radiocarbon date to $\sim 9.0 \mathrm{ka}$ (Stansell et al., 2013). These ages combined with basal ages from the Jahuacocha sediment core suggest that the lake formed after the early Holocene glacier retreated up valley, and that the glacier terminus subsequently remained above that elevation.

Very little work regarding the timing of Late Glacial deglaciation has been done in the Cordillera Raura. A radiocarbon age of $14.7 \mathrm{ka}\left(12.5 \pm 0.3{ }^{14} \mathrm{C} \mathrm{kyr} \mathrm{BP}\right)$ from peat inside a Lateglacial moraine on the eastern side of the Cordillera Raura provides a minimum age for deglaciation (Cardich et al., 1977). There are no existing records that span the remaining Late Glacial and early Holocene, however, the Lutacocha record from the Cordillera Raura contains a basal radiocarbon age of 9800 years suggesting that at least one readvance occurred (Stansell et al., 2013).

\subsection{Junin Region}

Wright conducted surveys in the Junin Region that provided additional time constraints on late-glacial to Holocene glaciations (Wright, 1983, 1984). He observed two distinct phases of Pleistocene glacier advances, the Rio Blanco and the Punrun, and concluded that deglaciation from the younger began by at least $\sim 14$ ka calibrated $\left(12{ }^{14} \mathrm{C} \mathrm{k}\right.$ yr BP) based on basal ages from Rio Blanco pond (Wright, 1983; Rodbell et al., 2009). The mapping efforts relied on careful distinction of superposition and relative dating of moraines, till and outwash. A section of buried organic lake sediments beneath the Punrun till were dated at $>42{ }^{14} \mathrm{C}$ kyr BP (SI-1491), and give a minimum for the underlying and slightly more expansive Rio Blanco glaciation. However, constraining the timing of deglaciation from the Punrun is difficult given the potential for dead ice to have remained on the till plain, as well as the hard water effects in carbonate lakes that influenced the radiocarbon dates. Yet given the flat topography and low relief, the deglaciation was likely rapid. A layer of clay within sediments between depths of 12 and $21 \mathrm{~m}$ extracted from L. Junin was interpreted to be outwash from Punrun glaciers; bounding dates (uncalibrated): 23,980 320 (Beta3217) and 12,010 $\pm 110 \mathrm{yr}$ B.P. (Beta-3216).

In a second publication, Wright (1984) reassessed a readvance for glaciers terminating about $10{ }^{14} \mathrm{C}$ kyr BP that he calls the Taptapata. However, the description of moraines is not clear, and reported dates from lakes are contradictory. Wright suggested the lake dates may be too old given carbonate bedrock and hard water effects.

Smith et al. (2005) published $146 \mathrm{TCN}$ dates sampled from boulders and bedrock exposures in four of the valleys east of Lake Junin, draining the Cordillera Oriental. These ages cluster into four groupings (A to D), with the oldest (C and D) having ages considerably older ( $>65 \mathrm{ka}$ to $>200 \mathrm{ka}$ ) than the last glacial cycle. The second to youngest is what the authors called the LLGM, and recalculated values show ages spanning from $\sim 32$ to $27 \mathrm{ka}$, that predate the LGM and are midway down the valleys. A second late-glacial moraine 1-2 km upvalley from the LLGM moraines typically dams lakes and has dates ranging from $\sim 21-19 \mathrm{ka}$. A third, smaller group of late glacial moraines dates to $\sim 18 \mathrm{ka}$. 
Notably, the paleoglacier valleys that were sampled are broad low gradient valleys without modern glaciers, with maximum headwall elevations of $\sim 4600 \mathrm{~m}$. Three of the valleys (Alcacocha, Antacocha, and Calcacocha) drain westward to the Junin plain, with a total relief of only $\sim 500 \mathrm{~m}$. Moraines in only one eastern draining valley, Collpa, were sampled, and reveal ages of group C (LLGM). The interpretation is that the LLGM was much earlier than the global LGM, and that deglaciation proceeded rapidly after $15 \mathrm{ka}$, when the moisture conditions on the Altiplano dried. They make links to the Pacific SST record, and global ice volume, suggesting a decoupling in the timing of Andean mountain glaciers from the global ice sheets.

\subsection{Nevado Huaguruncho}

Lake sediments and TCN exposure ages provide a detailed integrated record of the timing of Late Glacial and Holocene glacial activity at Nevado Huaguruncho in the Eastern Cordillera of the tropical Peruvian Andes (Stansell et al., 2015). Glaciers expanded ca. $14.1 \pm 0.4 \mathrm{ka}$, during the first half of the ACR. This was followed by an interval of ice retreat from 13.7-12 ka, an interval that spans most of the YD. Glacigenic clastic sediment proxies from Lake Yanacocha indicate an abrupt glacial expansion starting at ca. $12 \mathrm{ka}$ that culminated in moraines constructed from $11.6 \pm 0.2 \mathrm{ka}$ to $10.3 \pm 0.2 \mathrm{ka}$. Ice advanced or stabilized under colder and drier atmospheric conditions during the early Holocene.

This mountain setting features a currently glacierized central horn and converging arêtes that attain a maximum summit elevation just under $5700 \mathrm{~m}$, surrounded by lower gradient U-shaped valleys that radiate in different aspects. The features dated by Stansell et al. (2015) are contained within a broad cirque with lakes at $\sim 4300 \mathrm{~m}$ that captures glaciers with southerly and easterly aspect. The moraine mapped as bounding Yanacocha is parallel with other laterals that exit to the east and south, terminating $\sim 4000 \mathrm{~m}$. These are likely late-glacial in age, but do not extend to the limits of the longer glacial valleys of U-shape form, indicating earlier extensions of ice were larger.

\subsection{Cordilleras Vilcabamba, Vilcanota and Quelccaya}

Glacier moraines in the Cordillera Vilcabamba $\left(13^{\circ} 60^{\prime} \mathrm{S}\right)$, on the NW side of the Cordillera Vilcanota $\left(13^{\circ} 45^{\prime} \mathrm{S}\right)$, and the western side of the Quelccaya Ice Cap $\left(13^{\circ} 55^{\prime} \mathrm{S}\right)$ have long been recognized for having multiple series of relic moraines. In the Cordillera Vilcabamba, TCN ages indicate an outer distal moraine (Sisaypampa) dates to $12.9 \pm 0.9 \mathrm{ka}$, the Rio Blanco outer moraine has ages of $11.1 \pm 0.4 \mathrm{ka}$, and the Sisaypampa outer proximal moraine dates to $10.5 \pm 0.7 \mathrm{ka}$ (Licciardi et al., 2009). Mercer discovered impounded peat in the Upismayo valley draining to the NW from Ausengate $(6387 \mathrm{~m})$, the highest summit of the Vilcanota, that gave the first maximum limiting radiocarbon date for a late-glacial advance at $14{ }^{14} \mathrm{C} \mathrm{k}$ yr BP (Mercer and Palacios, 1977). The site was revisited and a full section of peat exposed that gave a maximum age for the late-glacial moraines of $16.7 \pm 0.4 \mathrm{ka}$. and a minimum age of $41 \mathrm{ka}$ for the older moraines terminating further down valley where a broad till plain ends with moraines as low as $3600 \mathrm{~m}$ near Ocongate (Goodman et al., 2001; Mark et al., 2002). On the Quelccaya side, Mercer named the Huancane 1, 2 and 3 
(H1-3) moraine stages as successively older and more extensive ice margins around the largest tropical ice cap, Quelccaya (Mercer and Palacios, 1977). The oldest H3 extension was constrained by a minimum of $14.3 \mathrm{ka}$, and a buried peat under $\mathrm{H} 2$ gave a maximum age of $12.8 \mathrm{ka}$. More comprehensive late-moraine mapping and chronology studies featuring abundant radiocarbon ages further delimited deglaciation from the lateglacial advance with additional minimum ages for $\mathrm{H} 3$ positions of 13.6-12.8 ka, as well as a readvance culminating at 12.5-12.4 ka that then receded quickly to Holocene limits by $11.6 \mathrm{ka}$ (Kelly et al., 2012). Late Holocene moraines were also dated in high detail (Stroup et al., 2014). Ample material for maximum and minimum dates constrain a date of $12.35 \mathrm{ka}$ for $\mathrm{H} 2 \mathrm{a}$ moraine, allowing for ${ }^{10} \mathrm{Be}$ production rates to be calculated (Kelly et al., 2015).

\subsection{Cordillera Ampato - Nevado Coropuna, Hualca Hualca}

Bromley et al. (2009) conducted thorough geomorphological field mapping on Coropuna, and published a map of glacial deposits, along with ${ }^{3} \mathrm{H}$ ages for LGM and Late Glacial ages. The distribution and stratigraphy of drift deposits and TCN dates suggest a late Pleistocene maximum $\sim 25-15 \mathrm{ka}$, followed by recession from the $\mathrm{C} 1$ moraines over 7-6 ka before a late glacial advance to $\mathrm{C} 2$ moraines dated $\sim 13 \mathrm{ka}$. At least two older pre-C1 advances are inferred from more extensive drift. Recalculating these ages using updated calibration methods yields values that are slightly different than the original published data (Bromley, personal communication). Nevertheless, their data indicate an older advance occurred from 25.3 to $24.5 \mathrm{ka}$ near the LGM, and another cluster of somewhat younger ages from $\sim 21.1$ to $20.7 \mathrm{ka}$. There are Late Glacial ages that cluster around 19.4 to 14.9 , and another group from 13.3 to $10.6 \mathrm{ka}$.

Alcalá et al. (2011) used cosmogenic ${ }^{36} \mathrm{Cl}$ isotopes to date moraine boulders on the Hualca Hualca stratovolcano $\left(15^{\circ} 49^{\prime} \mathrm{S}\right)$ in the Cordillera Occidental in southern Peru, near Arequipa. The LLGM here occurred $\sim 17.9 \pm 0.1$ to $16.8 \pm 0.4 \mathrm{kyr}$. They determined that widespread deglaciation on the Patapampa Altiplano culminated at $\sim 12.6 \pm 0.4 \mathrm{kyr}$, but that moraines were still being constructed until $\sim 12.0 \mathrm{kyr}$, suggesting that multiple readvances occurred.

\subsection{Cordilleras Carabaya and Apolobamba}

In the Cordillera Apolobamba $\left(14^{\circ} 35^{\prime}-15^{\circ} \mathrm{S}\right)$, lakes and peatlands bounded by Late Glacial moraines have radiocarbon ages that date between 12.5 and $9.0 \mathrm{ka}$ (10.5 \pm 0.1 to $\left.8.1 \pm 0.2{ }^{14} \mathrm{Cka}\right)$ (Seltzer, 1990).

The Cordillera Carabaya $\left(14.3^{\circ} \mathrm{S}\right)$ is on the eastern edge of the Altiplano, south of the Quelccaya Ice Cap, comprising relatively low elevation ridges $(<5200 \mathrm{~m})$ and broad valleys that drain southward to the Titicaca basin. Field mapping combined with TCN sampling yielded 10Be dates $(n=12)$ from two field sites, Laguna Acrimona and Minas Tira, that range from $26 \mathrm{ka}$ to $15 \mathrm{ka}$ (Bromley et al., 2016). These ages were derived by applying the new high elevation tropical production rate calibrated at nearby Quelccaya (Kelly et al., 2015) and significantly affirm that the most extensive advance of the last glacial cycle pre-dates the LGM. 
At the Minas Tira site, the Quebrada Tirataña is a broad, curving, low-gradient valley draining to the south from draining Nevado Tolqueri $(5275 \mathrm{~m}$ asl), that defines a ridge with small remaining glaciers at $<5200 \mathrm{~m}$. The low relief site is grassy, broad, and lacks many large boulders. There are three distinct lateral-terminal moraines on the western, right-lateral edge, and multiple terminal crests that cross the valley. Four TCN samples were taken from boulders on these terminal moraines, and these have ages from 26-22 ka, showing oldest on the outer limit and consistently younger toward the inner. The close clustering is interpreted to mean that inheritance is limited. A tributary valley, Q. Jotini, has a prominent series of lateral and terminal moraines terminating proximal to, but not merging with, Q. Tirataña. The authors count 14 terminal ridges in the Minas Tira site within 500m (at 4550-4600 m). The paleoglacier that formed these was apparently draining a plateau with hummocky topography, lakes and wetlands $(\sim 4850 \mathrm{~m})$ about $4 \mathrm{~km}$ west of the summit ridge. Observing independently (using GE), this was likely an outlet glacier from an old ice cap. Also visible on GE is a series of lateral-terminal moraines draining $\mathrm{W}$, with a defined upper edge to the left-lateral at $\sim 4770$ m that could have been the ice cap ELA (i.e. Porter, 2001). There is a series of terminal moraines damming a lake $\sim 2.5 \mathrm{~km}$ upvalley from the Minas Tira termini that were not described in the paper.

Laguna Aricoma is $\sim 50 \mathrm{~km}$ to the ESE and is one of a series of lake filled valleys draining to the south from an E-W trending ridge with headwall summit elevations $<5200 \mathrm{~m}$ and very small remnant glaciers. The valleys feature a prominent series of inset lateral-terminal loops damming lakes with cross-cutting stratigraphy that clearly indicates that the younger moraines were a readvance that the authors name Veluyoccocha after the lake impounded by the moraine. Two granite boulders from the outer ridge of the older composite right-lateral moraine date to $19 \mathrm{ka}$. The dates from the terminus $(n=2)$ of the Veluyoccocha readvance come in at around $16 \mathrm{ka}$. Proximal to the limits, two younger right-lateral moraine ages are 15.5 and $15.2 \mathrm{ka}$.

The authors interpret these results to suggest that glaciers attained their maximum extent earlier than LGM, with an MIS 2 advance in place by 28 ka that remained close to its limit throughout the LGM, at least until $19 \mathrm{ka}$. If the $19 \mathrm{ka}$ is a deglacial age, it represents termination 1 . Then, by $16 \mathrm{ka}$, there had been rapid recession of $\sim 50 \%$ of the length before subsequent re-advance at that time. The slightly contrasting moraine sets in the two different valleys also constrains the late-glacial readvance. The $16 \mathrm{ka}$ event that does demarcate a nice ridge and dam lakes to the East at Aricoma where there is a slightly higher headwall, and summits $\sim 5200 \mathrm{~m}$ (currently tiny glacierettes).

\subsection{Cordillera Real}

In the San Francisco valley, Zech et al. (2007) dated 2 sets of Late Glacial moraines using ${ }^{10} \mathrm{Be}$. The older set dated from 18.9 to $13.7 \mathrm{ka}$. The younger set dated from 15.3 to $14.6 \mathrm{ka}$. In the Zongo valley of the Cordillera Real $\left(16^{\circ} 17^{\prime} \mathrm{S}\right)$ to the southeast, minimumlimiting Late Glacial moraine ages date to $\sim 11.2 \mathrm{ka}\left(9.8 \pm 0.1{ }^{14} \mathrm{Cka}\right)$ (Seltzer et al., 1995). In the same Zongo valley, TCN ages on older Late Glacial moraines range from 21.9 to $14.2 \mathrm{ka}$. A younger group of Late Glacial moraines dates from 18.1 to $14.1 \mathrm{ka}$ 
(Smith et al., 2005). Basal sediments from moraine-dammed lakes and peatlands in the Palcoco and Milluni valleys have radiocarbon ages that range from 12.8 to $10.9 \mathrm{ka}$ (10.9 \pm 0.1 to $9.6 \pm 0.1{ }^{14} \mathrm{Cka}$ ) (Seltzer, 1992). Smith et al. (2005) reported TCN ages of late glacial moraines that date from 19.4 to $10.3 \mathrm{ka}$.

Illimani massif $\left(16^{\circ} 39^{\prime} \mathrm{S}\right)$ rises to a summit elevation of $\sim 6400 \mathrm{~m}$ at the southern end of the Cordillera Real, separated from the range by the east-draining Khañuma Valley that drains to the SE of La Paz. A geomorphic mapping and chronology study featuring $23{ }^{10} \mathrm{Be}$ samples of granodiorite boulders along moraines in the north-facing Pasto Grande valley identified three series of moraines (A - C from oldest to youngest) that are interpreted to represent initiations of deglaciation from late glacial, early and late Holocene positions (Smith et al., 2011). Since these moraine ages are not in the Shakun et al. (2015a) composite, we recalculated the ages using the Quelccaya production rates and constant production model using the CRONUS on-line calculator. The recalculated ages suggest that glaciers retreated, or experienced stillstands sometime after $\sim 16.6 \mathrm{ka}$, $15.1 \mathrm{ka}$, and $10.1 \mathrm{ka}$. The most extensive glacial advance showed ELA depressions computed to be 400-600 m, consistent with other localities along the Eastern Cordillera.

The oldest dated Group A moraines are subdivided into A1 and A2 because the forms are not continuous between lateral and end moraine. Nor are the moraines detected from GE imagery, but can be located by elevation within the valley. The Pasto Grande valley stream descends as low as $3850 \mathrm{~m}$ before converging with a southern aspect glacial valley draining from a $5800 \mathrm{~m}$ summit at Tres Rios before draining to the east in the main Khañuma Valley. Well-defined left-lateral moraine ridges are visible at this confluence, indicating paleoglacial extension predating the lateglacial Group A that extended lower $(<3500 \mathrm{~m})$, but no dates are available.

\subsection{Cordillera Cochabamba}

The Wara Wara Valley of the Cordillera Cochabamba $\left(17^{\circ} 17^{\prime} \mathrm{S}\right)$ is currently not glacierized, and comprises a broad U-shaped valley rising to a headwall ridge crest at $4300 \mathrm{~m}$. The valley was investigated and a series of inset moraines sampled in 5 clusters (oldest to youngest, W1-W5) for TCN dating (Zech et al., 2010). The ages of the two oldest clusters that are sampled on closely inset R-lateral ridges, are interpreted as correlating with $\mathrm{H} 1$ (W1) and the YD (W2), with the recession between them thus aligning with the BollingAlerod period. The authors suggest that the timing of advances and retreats corresponds to SST changes in the eastern tropical Pacific as recorded by Kienast et al. (2006). They also corroborate this with inverse paleoglacier modeling from the region (Kull et al., 2008) to suggest wetter conditions prevailed for these advances, consistent with pluvial conditions that raised Altiplano lakes (Placzek et al., 2006). The recalculated ages, however, place these moraine groups from oldest to youngest at $19.8 \pm 1.5$ (W1), $16.9 \pm 0.9$ (W2), $15.0 \pm 0.8$ (W3), $14.9 \pm 0.6$ (W4), and $12.8 \pm 0.9$ (W5) ka. The W1 moraines thus appear to represent post-LGM ice extent, followed by the W2 moraines that date within the Oldest Dryas.

The authors orginally describe an early Holocene readvance at $\sim 10 \mathrm{ka}$ based on the W3 and W4 moraines, however the recalculated ages place these closer to the ACR. 
These are much smaller forms in the valleys, and W4 is upvalley but almost identical in age to W3. The low ridges may therefore also represent recessionals and not distinct readvances of paleoglaciers in the ACR. Complete deglaciation of the valley was apparently rapid and completed by $13 \mathrm{ka}$, based on the W5 ages from boulders on hummocky terrain close to the headwall.

\subsection{Sajama}

Sajama $\left(18^{\circ} 07^{\prime} \mathrm{S}, 68^{\circ} 53^{\prime} \mathrm{W}\right)$ is a stratovolcano rising to $6542 \mathrm{~m}$ on the eastern side of the Western Cordillera with an extant ice cap that was cored to bedrock, yielding a $25 \mathrm{k}$ yr paleoclimate record (Thompson et al., 1998). Comprehensive field mapping and TCN dating of the moraines surrounding Sajama shows a late glacial advance that was cold based, with Cl-36 ages ( $\mathrm{n}=36)$ coming in at 16-10 ka (Smith et al., 2009). Combined with minimum radiocarbon ages behind inset moraines, the data show glacier recession was initiated from early and mid-Holocene positions at 7-4.4 ka, and 4.7$3.3 \mathrm{ka}$. The dates are presented as a range, spread between the arithmetic mean and maximum TCN date.

The relative change in conditions from cold-based late glacial extent to warmbased Holocene glaciation suggests that deglaciation featured significant alterations of precipitation and temperature in this part of the now arid western Altiplano.

\subsection{Central Altiplano}

Aridity increases towards the southern limit of Bolivia, where only the eastern cordillera is glaciated. Multiple archives indicate that glaciers remained advanced in the Salar de Uyuni region well after the global LGM. Clayton and Clapperton (1997) identified till and outwash associated with the local LGM on Cerro Azanques that folded peat with a maximum-limiting age of $\sim 16.7 \mathrm{ka}\left(14.0 \pm 0.1\right.$ to $13.3 \pm 0.1{ }^{14} \mathrm{C}$. Clapperton (1998) presented an additional 10 unpublished ${ }^{14} \mathrm{C}$ ages on the same peat deposits that range from 15.9 to $15.1 \mathrm{ka}\left(13.4\right.$ to $\left.12.9{ }^{14} \mathrm{C}\right)$ as support for the timing of the local LGM. These deposits have alternatively been interpreted by Heine (2000) as mass wasting events.

More recently, cosmogenic ${ }^{3} \mathrm{He}$ ages of glacial landforms from Cerro Tunupa support the earlier evidence of Clayton and Clapperton (1997), and indicate that glaciers associated with the last glacial cycle were at their maximum extent until $\sim 15 \mathrm{ka}$ (Blard et al., 2009). The firm chronology suggests that local LGM conditions correspond to cold and wetter conditions during the paleolake Tauca highstand between $\sim 17$ and $15 \mathrm{ka}$ (Clapperton et al., 1997; Clayton and Clapperton, 1997; Placzek et al., 2006; Blard et al., 2009). Moraines of similar ages have been identified at Sajama with the outermost features dating from 16.9 to $11.8 \mathrm{ka}$, and another batch of ages dates somewhat younger from 14.0 to $10.2 \mathrm{ka}$ (Smith et al., 2009). There is also evidence of a glacial readvance sometime between 13.2 and $12.3 \mathrm{ka}$, which possibly occurred during the Younger Dryas, followed by a complete deglaciation of Tunupa after $\sim 12 \mathrm{ka}$ (Blard et al., 2009). 


\section{Discussion: Synthesis of dates and climate events}

Although considerable uncertainty remains regarding the age distributions for specific moraine chronologies, a general deglacial sequence is apparent when considering post LGM. Sedimentary sequences in Titicaca and Junin, along with compilations of multiple smaller lakes closer to headwalls (i.e. Rodbell et al., 2008) provide evidence that the maximum extent of glaciers predates the LGM. Regardless of initiation, many TCN dates on moraines and $14 \mathrm{C}$ dates from sediments fall within a range close to the LGM, suggesting that after the global LGM, glaciers either lingered at select locations for several millennia, or ice experienced a readvance. One of the earliest identified close minimum limiting age for glaciation near the global LGM is from Laguna Kollpa Kkota, Bolivia (Seltzer, 1994), where $14 \mathrm{C}$ dates from sediments behind moraines delimited the impounding moraine from 23-20 ka. Many moraines do not have dates constraining them, especially max limiting ages. On the other hand, moraine loops at Calcalcocha and Alcacocha in the Junin region yield near-LGM ages ( 22 to $20 \mathrm{ka}$ ). There are also similar ages on the San Cirilo moraine near Cajamarca, the M6 moraine in the Juellesh Valley of the Cordillera Blanca, and the C1 moraine on Coropuna. In all, the available TCN ages on groups of moraines that date near the timing of the LGM have a mean of $25.1 \mathrm{ka}$, and standard deviation of $4.0 \mathrm{ka}$. Notably, there is considerable uncertainty in these apparent LGM ages (up to $\pm 7.2 \mathrm{ka}$ ), especially for boulders with ages greater than $\sim 24 \mathrm{ka}$, and thus, the timing of the local LGM should be interpreted cautiously. It is also worth noting that the range in possible scaling factors and production rates is another source of uncertainty, however, these variables lead to only $\sim 10 \%$ differences in the final calculated ages throughout this study.

There is some evidence of post-LGM moraine abandonment in the southern tropical Andes. The mean age for all observed groups of post-LGM boulders is $18.9 \mathrm{ka}$ with a standard deviation of 0.5 . While uncertainties in ages for individual moraine groups range from 0.8 to $4.3 \mathrm{ka}$, it is clear that a significant number of boulders have ages that are younger than the LGM. In the Antacocha and Calcalcocha valleys near Junin, there is another cluster of moraine ages between 20 and $18 \mathrm{ka}$. Moraines near Cajamarca, the Carhuacocha valley of the Cordillera Huayhuash, and the Cordillera Blanca also date within this post-LGM interval. Dated boulders in the outer tropics of Bolivia have also show signs of post-LGM deposition, including the Zongo group C, Huara Loma, Coropuna, and Cochabamba moraines.

Multiple valleys in Peru and Bolivia contain evidence of glacial advances during the Oldest Dryas ( 18 to $14.6 \mathrm{ka}$ ). The mean of all groups of moraine boulders that date within the Oldest Dryas is $16.1 \mathrm{ka}$ with a standard deviation of 1.1. The Alacacocha valley near Junin, the Juellesh and Tuco valleys of the Cordillera Blanca, and multiple valleys in the Cordillera Huayhuash all have moraine ages that date to within this interval. Further south in Bolivia, the Rio Suturi, Huara Loma, Wara Wara, and San Francisco valleys have moraine boulders that date to within the Older Dryas. Radiocarbon ages from the Cordillera Vilcanota provide evidence that glaciers advanced sometime after $\sim 18.0$ to 16.8 BP (Mercer and Palacios, 1977; Mercer, 1984), and radiocarbon ages from the Altiplano indicate an advance occurred there from $\sim 17$ to $15.4 \mathrm{ka}$ (Clapperton et al., 1997; Clapperton, 1998). 
There is evidence for glaciers advancing in multiple regions of Peru of Bolivia during the ACR (14.6 to $12.6 \mathrm{ka}$ ). The mean of all groups of moraine boulders that date within the ACR is $13.7 \mathrm{ka}$ with a standard deviation of 0.8 . Periods of cooling at the beginning and end of the ACR can be identified in the ice core record from Nevado Huascaran in the Cordillera Blanca, which is consistent with other glacial-geologic evidence. Moraine ages from the Cordillera Huayhuash date to the start of the ACR, whereas the Breque valley in the Cordillera Blanca, and the Cordillera Vilcabamba has moraine ages that date to the end of the ACR. Moraines in the Eastern Cordillera of Peru at Nevado Huaguruncho also date to the start of the ACR. In Bolivia, boulders from the Wara Wara valley date to the start of the ACR, while the Mulluni and Telata glaciers date closer to the middle of the ACR (13.6 and $13.4 \mathrm{ka}$, respectively).

Referencing the Sajama and Huascaran ice cores spanning to the late-glacial, there is an apparent Deglacial Cold Reversal (DCR) that happens $~ 1000$ yrs prior to the initiation of the YD, and covers the time of glacier readvance. Then, while the $\mathrm{NH}$ is experiencing peak cold of YD, the glaciers rapidly recede. The evidence of this recession is constrained by minimum ages behind the moraines. It ties into a site in Bolivia (Abbott et al., 1997), where a cirque lake (16S, headwall $5650 \mathrm{~m}$ ) shows min age of $12.7 \mathrm{ka}\left(10.7 \mathrm{k}{ }^{14} \mathrm{C} \mathrm{yr} \mathrm{BP}\right)$. Because the regional conditions were cold, this rapid retreat was initially interpreted to be caused by local aridity, and a non-linear response to changing insolation.

Clapperton (1993) also compiled best dated sites to make a statement that there was compelling evidence for synchronous glacier advances throughout the Andes during the 12.5-10 ka interval ("suggestive if not yet persuasive"), and thus a Late-glacial climate shift that was widespread throughout the range. The Breque site in the Cordillera Blanca has evidence that suggests glaciers advanced just prior to, or at the start of, the YD. Similar evidence from the Vilcabamba in southern Peru suggests ice advanced at the start of the YD, but then ice retreated. The early work of Mercer and Palacios (1977) provides evidence that ice advanced near Quelccaya near the start and end of the YD. Similarly, Kelly et al. (2015) provide additional radiocarbon-based evidence that the Quelccaya Ice Cap advanced at the start of the YD, followed by retreat.

The idea of an early and rapid ice margin fluctuation in the tropical Peruvian Andes around the YD was put forward by Seltzer and Rodbell (2000) in consideration of glacial fluctuations at three key Peruvian sites near the YD. In Peruvian tropical Andes, they point at three localities reporting some glacier activity during the YD time:

1. Quelccaya Ice Cap: The radiocarbon evidence suggested initially that there was an ice advance to a position $\sim 6 \mathrm{~km}$ from modern ice that likely predated the YD (H2 moraine, 14.2 to $12.9 \mathrm{ka}$, from Mercer and Palacios, 1977). Rodbell and Seltzer (2000) published a minimum age of 12.9 ka from basal peat over glacial sediments in Pacococha, $500 \mathrm{~m}$ upvalley and closer to the ice edge, while Kelly et al. (2012) argue this was too old, and refer to other sediments dating to $11.6 \mathrm{ka}$ as minimum.

2. Cordillera Oriental, Northern Peru: sediment records in lakes (Rodbell, 1993b) showed some evidence of readvance and reoccupation of higher cirques by glaciers, but no exact moraine has been dated. 
3. Cordillera Blanca, Breque site. Detailed stratigraphy, cross-cutting moraines and closer limiting maximum and minimum ages place an ice advance to within $10 \mathrm{~km}$ of the modern glacier (with summit elevation $5700 \mathrm{~m}$ ) between 13.1-12.8 ka. The TCN ages of 8 boulder samples from Farber et al. (2005) come in at $12.7 \mathrm{ka}$.

There is growing evidence of early Holocene advances in the Central Andes. The mean of all groups of moraine boulders that date within the early Holocene is $11.0 \mathrm{ka}$ with a standard deviation of 0.4 . For example, multiple valleys in the Cordillera Huayhuash have TCN ages that date between 11.4 to $10.5 \mathrm{ka}$, suggesting that glaciers either experienced a stillstand or readvance during the early Holocene. Early Holocene features are also well-dated at Huaguruncho (11.6 to $10.5 \mathrm{ka}$ ), and a moraine loop in southern Peru at Cordillera Vilcabamba dates to $\sim 10.5 \mathrm{ka}$. Basal radiocarbon ages from Lutacocha in the Cordillera Raura suggest conditions became ice free, locally, soon after $9.4 \mathrm{ka}$. In the Vilcanota/QIC, till overlying peat dated to 11.1 and $10.9 \mathrm{ka}$ give maximum limiting ages for the Huancane II moraines (of Mercer and Palacios, 1977), suggesting an early Holocene advance. Other sites recognizing this included Wright's mapped Taptapa moraine at $10.1 \mathrm{ka}$ (Wright, 1984), followed by rapid deglaciation. The Quelccaya Ice Cap was recognized to be at the limit by $10 \mathrm{ka}$, given peat exposed at the margin (Thompson et al., 2006; Buffen et al., 2009).

The climatic forcing of deglaciation remains an important object of research, especially the Pleistocene Holocene transition that represents the most recent largescale climate transition between radically different boundary conditions. The tropical Andes remain an especially important region to study this given its location between hemispheres. There has been much work over the past three decades compiling basic observations from glaciated terrain in these parts of the Andes that document significant variability in climatic conditions that allow glaciers to persist or not. Better age control and broader field coverage has resulted in a steady increase in the understanding of the nature and extent of glacier advances.

Clapperton (1993) was one of the first to compile the available evidence from a variety of paleoenvironmental sources for the entire South American continent to hypothesize the climatic context for the pattern and nature of LGM deglaciation. The few dates available on glacial moraines and lake levels led him to conclude that an early LGM advance (34-27 ka) for the Central Tropical Andes was supported by cold conditions, with enough humidity (i.e. higher lake levels) to support glacier advance. Yet shortly afterwards, as the global LGM was approached, conditions became more arid, forcing deglaciation. With better age control, however, many of these features were alternatively interpreted instead as being associated with late-glacial advances.

In synthesizing the available TCN dates, Zech et al. $(2008,2009)$ discuss that there is a consistent pattern of an early LGM advance, followed by late glacial advance, and rapid deglaciation that is seen in Peru in the Cordillera Blanca and around Junin, and in both the Cordilleras Real and Cochabamba in Bolivia. They pose a hypothesized climatic framework to explain the regional variation whereby the availability of adequate humidity in the tropical Andes makes them more prone to temperature changes, and the glacial advances are in synch with northern high latitudes. While there remain 
differences in dates resulting from choices of production rate and scaling factors made by different researchers, Zech co-authored a chapter with other regional researchers that listed explicitly different ages, but show how the overall pattern remains consistent (Zech et al., 2009).

While overall patterns of glacial-interglacial fluctuations are paced by orbital forcing, the mechanisms that can explain global synchronous changes are unclear. Gradual insolation changes focused on the mid-high latitudes of the $\mathrm{NH}$ are insufficient. More specifically, rapid shifts between warmer and colder states seen in records around N. Atlantic imply close coupling between oceanic and atmospheric dynamics not forced by slower, steady shifts in radiation. Nevertheless, these broad-scale oscillations most clearly identified in the North Atlantic region indicate abrupt climate changes that may or may not have had global impacts. A key example is the warm to cold transition recorded in isotopic records from Europe and Greenland ice cores revealing a late glacial climate sequence from a warm Bølling-Allerød (B/A) event followed by the cold YD, before the initially warm Holocene.

The synchroneity or asynchroneity of glacial variability in the tropical Andes relative to the high latitudes of the Northern and Southern Hemispheres is an area of active research. The premise of a global synchroneity of the glacial-interglacial transition implies something leveraging the slow progressive insolation changes to impose control globally. For example, Shakun et al. (2015a) suggest globally synchronous glacial variability at the start of deglaciation forced by $\mathrm{CO}_{2}$ increases. However, regional climatic forcing likewise imposes major controls on glacial variability, and no one single mechanism can explain the timing of ice margin changes at all locations. Indeed, Shakun et al. (2015a) note that tropical Andean glaciers show a pronounced early initiation of recession that was likely due to ENSO, or hypsometry. Given the sensitivity of tropical Andean glaciers to SST changes (Bradley et al., 2009), it seems logical to focus our attention on coupled ocean-atmospheric processes, with rising $\mathrm{CO}_{2}$ as a possible critical feedback, to explain the pattern of glacial variability observed across the tropical Andes. One possible mechanism is AMOC changes associated with an orbitally induced retreat of Northern Hemisphere ice sheets (He et al., 2013). Temperature changes in the Huascaran ice core record have been interpreted to be the result of SST variability in the North Atlantic (Thompson et al., 1995), and North Atlantic conditions strongly modulate the strength of the South American Summer Monsoon and precipitation dynamics in the tropical Andes (Bird et al., 2011; Vuille et al., 2012). The tropical Pacific Ocean also modulates circulation dynamics, precipitation amounts, and temperature in the Andes, and may have influenced western Andean ranges differentially over time (Smith et al., 2009). Other work in New Zealand and mid-latitude Chilean Lakes district (Doughty et al., 2015) also show a decoupling of glacier advances from local summer insolation that seems convincingly to pace the large Northern hemisphere ice sheets. In contrast, these southern mid-to-high-latitude sites suggest that glacier extent during the last termination was aligned with Southern Ocean surface temperature and with atmospheric carbon dioxide.

In the tropical Andes, glacier recession was occurring by $20 \mathrm{ka}$, and sedimentary records suggest that temperature (and perhaps greenhouse gas concentrations) were 
driving a rapid $1000 \mathrm{~m}$ snowline rise. A 24.7 ka lake sediment record from Lake Pacucha near Andahuaylas shows a transition from relatively wet and cool conditions in the LGM, with a marked late-glacial transition to a dry early Holocene (Hillyer et al., 2009). At Lake Titicaca, glaciers were in recession by 22-20 ka, even while wetter conditions prevailed from $25-15 \mathrm{ka}$ based on fresh and overflowing conditions (Seltzer et al., 2002). This is further consistent with the existence of deep lake conditions on the now dried Salar de Uyuni salt flat from $26 \mathrm{ka}$ to $15 \mathrm{ka}$. The wet conditions inferred by lake levels prevailed while insolation reached a maximum at $20 \mathrm{ka}$, and reduced to a minimum at $10 \mathrm{ka}$. Moreover, the initiation of deglaciation is more closely aligned to methane-tuned Antarctic ice core evidence of warming that initiated thousands of years prior to the $\mathrm{NH}$, leading to the conclusion that tropical warming may have led deglacial warming at higher latitudes by $~ 5000$ years. In relating both Titicaca and Junin sediments (i.e. Seltzer et al., 2000) as continuous records beyond the limit of glaciation, Seltzer et al. (2002) use peaks in magnetic susceptibility to document glacier advances, and the drop in such sediments as the initiation of deglaciation, since the coarse sediments were accumulating behind terminal moraines uphill. The Junin record shows glacial inputs of high magnetic susceptibility initiated $\sim 30 \mathrm{ka}$, and persisted until an abrupt end at $22.5 \mathrm{ka}$. The further analysis of diatoms and carbonate conditions shows that the lake was relatively full of water during the initial deglaciation, suggesting the conditions were wet, and remained so until $\sim 16 \mathrm{ka}$. These wet conditions during initial deglaciation appear to be synchronous with temperature changes in the Northern Hemisphere whereby the strength of the SASM increased during cold periods (Kanner et al., 2012). Conditions then became drier during the ACR at a time glaciers were advancing in multiple valleys throughout the southern tropical Andes. During the YD time, Titicaca was fresh and overflowing, followed by a dry spell from 11.5-10 ka while conditions were relatively wet at Lake Junin (Seltzer et al., 2000).

Based on the available evidence, the deglaciation of the tropical Andes of Peru and Bolivia appears to be in-phase at times, and other times out-of-phase with cooling and warming trends in the Northern Hemisphere. Even though age control need to be refined, cooling during the Oldest Dryas of the Northern Hemisphere appears to correspond to ice advances in the tropical Andes. However, glaciers advanced during the B-A warming of the Northern Hemisphere, and thus Andean glacial records appear to be more in phase with the ACR during that phase. Likewise, glaciers retreated in the southern tropical Andes during the YD cold phase of the Northern Hemisphere, and then readvanced during early Holocene warming in the Northern Hemisphere.

\section{Conclusions and outstanding questions}

Studying the deglacial history of the tropical Andes reveals a complicated pattern of ice margin fluctuations, and precisely how the combined influences of both temperature and precipitation changes affected glaciers in the tropical Andes is unresolved. Early work in the Central Andes, based largely on radiocarbon dating methods, sparked considerable discussion regarding the timing and causes of post- 
LGM climatic fluctuations in the tropics. More recent work that utilized cosmogenic dating methods has considerably improved our ability to date the timing and position of past ice advances and/or stillstands of glaciers. A major limitation of cosmogenic dating methods, however, is the discontinuous nature of moraine chronologies. More continuous records, like proglacial lake sediments, provide a means to develop more comprehensive paleoclimate records when combined with cosmogenic ages on moraines. In addition, as detailed hydroclimate records using stable isotopes become more available, we are better understanding how precipitation patterns have varied in the past in order to better evaluate the timing and causes of glacial variability on range of time-scales.

The available records suggest that the deglacial sequence is characterized by overall ice retreat punctuated by periods of brief ice advances and/or stillstands. In particular, moraines developed during the Oldest Dryas while it was cold in the Northern Hemisphere. During the remaining Late Glacial, however, glaciers appear to have readvanced and/or paused from retreat during the ACR while it was cold in the southern high latitudes, and dry in the central Andes. Glaciers were advanced just prior to, or at the start of the YD, followed by retreat. It remains unclear, however, how aridity during the YD might have played a role in ice retreat. Recently developed records suggest that an early Holocene ice advance, or stillstand, also occurred in the southern tropical Andes when the Northern Hemisphere was reaching near peak insolation values.

Questions still remain regarding the forcing mechanisms for deglaciation in the tropics. Precession likely drove the pattern of overall retreat, but other ocean and atmospheric mechanisms must have contributed to the glacial variability that interrupted the overall trend. While atmospheric $\mathrm{CO}_{2}$ no doubt played a role in the deglaciation of the tropical Andes, internal modes of variability like ENSO, and other coupled oceanatmospheric processes in the tropical Pacific and Atlantic Oceans must have been contributing factors. As records of glacial variability and paleoclimate records from terrestrial and marine locations continue to be developed at higher resolution, we need to improve our limited understanding of the climatic forcing mechanisms that caused ice margins to advance and retreat.

Future geomorphologic work should continue to seek localities to develop both sedimentary and moraine ages. There remain obvious regions lacking records (i.e. Fig. 1, regions between Cusco and the Junin Plain). Focusing on regions below thresholds of modern glaciers that also feature glacial lakes and moraines increases the likelihood of establishing pre-Holocene extents without the possible complications of Holocene readvances. Moreover, new techniques in exposure age dating using paired in situ ${ }^{10} \mathrm{Be}$ and ${ }^{14} \mathrm{C}$ measurements from bedrock exposures (Goehring et al., 2011; Goehring et al., 2013) that have promising potential to assist in untangling the complex histories and extent of mass changes during repeated glacier advances and retreats would be a high priority for ongoing research. 




Figure 1: Location map of the major sites referenced in the paper, with key references cited.

\section{References}

Abbott, M.B., Seltzer, G.O., Kelts, K.R., Southon, J. 1997. Holocene Paleohydrology of the Tropical Andes From Lake Records. Quaternary Research 47, 70-80. https://doi.org.10.1006/ qres.1996.1874.

Alcalá, J., Palacios, D., Zamorano, J.J., Vázquez Selem, L. 2011. Last Glacial Maximum and deglaciation of Ampato volcanic complex, Southern Peru. Cuaternario y Geomorfología 25, 121-136.

Baker, P.A., Rigsby, C.A., Seltzer, G.O., Fritz, S.C., Lowenstein, T.K., Bacher, N.P., Veliz, C. 2001a. Tropical climate changes at millennial and orbital timescales on the Bolivian Altiplano. Nature 409, 698-701. http://doi.org/10.1038/35055524.

Baker, P.A., Seltzer, G.O., Fritz, S.C., Dunbar, R.B., Grove, M.J., Tapia, P.M., Cross, S.L., Rowe, H.D., Broda, J.P. 2001b. The history of South American tropical precipitation for the past 25,000 years. Science 291 (5504), 640-643. https://doi.org/10.1126/science.291.5504.640. 
Bird, B.W., Abbott, M.B., Rodbell, D.T., Vuille, M. 2011. Holocene tropical South American hydroclimate revealed from a decadally resolved lake sediment $\delta^{18} \mathrm{O}$ record. Earth and Planetary Science Letters 310 (3-4), 192-202. http://doi.org/10.1016/j.epsl.2011 .08.040.

Birkeland, P.W., Rodbell, D.T., Short, S.K. 1989. Radiocarbon-Dates on Deglaciation, Cordillera Central, Northern Peruvian Andes. Quaternary Research 32 (1), 111-113. http://doi. org/10.1016/0033-5894(89)90036-7.

Blard, P.H., Lavé, J., Farley, K.A., Fornari, M., Jiménez, N., Ramirez, V. 2009. Late local glacial maximum in the Central Altiplano triggered by cold and locally-wet conditions during the paleolake Tauca episode (17-15 ka, Heinrich 1). Quaternary Science Reviews 28 (27-28), 3414-3427. http://doi.org/10.1016/j.quascirev.2009.09.025.

Bradley, R.S., Keimig, F.T., Diaz, H.F., Hardy, D.R. 2009. Recent changes in freezing level heights in the Tropics with implications for the deglacierization of high mountain regions. Geophysical Research Letters 36 (17). http://doi.org/10.1029/2009GL037712.

Bradley, R.S., Vuille, M., Hardy, D., Thompson, L.G. 2003. Low latitude ice cores record Pacific sea surface temperatures. Geophysical Research Letters 30 (4), 1174. http://doi. org/10.1029/2002GL016546.

Bromley, G.R.M., Schaefer, J.M., Hall, B.L., Rademaker, K.M., Putnam,A.E., Todd, C.E., Hegland, M., Winckler, G., Jackson, M.S., Strand, P.D. 2016. A cosmogenic ${ }^{10}$ Be chronology for the local last glacial maximum and termination in the Cordillera Oriental, southern Peruvian Andes: Implications for the tropical role in global climate. Quaternary Science Reviews 148, 54-67. http://doi.org/10.1016/j.quascirev.2016.07.010.

Bromley, G.R.M., Schaefer, J.M., Winckler, G., Hall, B.L., Todd, C.E., Rademaker, K.M. 2009. Relative timing of last glacial maximum and late-glacial events in the central tropical Andes. Quaternary Science Reviews 28 (23-24), 2514-2526. http://doi.org/10.1016/j. quascirev.2009.05.012.

Buffen, A.M., Thompson, L.G., Mosley-Thompson, E., Huh, K.I. 2009. Recently exposed vegetation reveals Holocene changes in the extent of the Quelccaya Ice Cap, Peru. Quaternary Research 72 (2), 157-163. http://doi.org/10.1016/j.yqres.2009.02.007.

Bush, M.B., Hansen, B.C.S., Rodbell, D.T., Seltzer, G.O., Young, K.R., León, B., Abbott, M.B., Silman, M.R., Gosling, W.D. 2005. A 17000-year history of Andean climate and vegetation change from Laguna de Chochos, Peru. Journal of Quaternary Science 20, 703-714. http:// doi.org/10.1002/jqs.983.

Cardich, A., Cardich, L., Rank, D. 1977. Datierung der jungpleistozanen Vereisung Lauricocha in den Peruanischen Anden. Geologische Rundschau 66, 446-454.

Chiessi, C.M., Mulitza, S., Pätzold, J., Wefer, G., Marengo, J.A. 2009. Possible impact of the Atlantic Multidecadal Oscillation on the South American summer monsoon. Geophysical Research Letters 36 (21), L21707. http://doi.org/10.1029/2009GL039914.

Clapperton, C.M. 1972. The Pleistocene moraine stages of west-central Peru. Journal of Glaciology 11 (62), 255-263. https://doi.org/10.3198/1972JoG11-62-255-263.

Clapperton, C.M. 1979. Glaciation in Bolivia before 3.27 Myr. Nature 277, 375-377. http://doi. org/10.1038/277375a0.

Clapperton, C.M. 1981. Quaternary glaciations in the Cordillera Blanca, Peru and the Cordillera Real, Colombia. Colombiana Revista CIAF (Bogota) 6, 95-111.

Clapperton, C.M. 1983. The glaciation of the Andes. Quaternary Science Reviews 2 (2-3), 83-155. http://doi.org/10.1016/0277-3791(83)90005-7.

Clapperton, C.M. 1993. Glacier readvances in the Andes at 12 500-10 000 YR BP: Implications for mechanism of Late-glacial climatic change. Journal of Quaternary Science 8 (3), 197 215. http://doi.org/10.1002/jqs.3390080303.

Clapperton, C.M. 1998. Late Quaternary glacier fluctuations in the Andes: testing the synchrony of global change. Journal of Quaternary Science 6, 65-73. 
Clapperton, C.M., Clayton, J.D., Benn, D.I., Marden, C.J., Argollo, J. 1997. Late quaternary glacier advances and Palaeolake highstands in the Bolivian Altiplano. Quaternary International 38, 49-59.

Clayton, J.D., Clapperton, C.M. 1997. Broad synchrony of a Late-glacial glacier advance and the highstand of palaeolake Tauca in the Bolivian Altiplano.Journal of Quaternary Science 12 (3), 169182. http://doi.org/10.1002/(SICI)1099-1417(199705/06)12:3<169::AID-JQS304>3.0.CO;2-S.

Coelho, C.A.S., Uvo, C.B., Ambrizzi, T. 2002. Exploring the impacts of the tropical Pacific SST on the precipitation patterns over South America during ENSO periods. Theoretical and Applied Climatology 71 (3), 185-197. http://doi.org/10.1007/s007040200004.

Doughty, A.M., Schaefer, J.M., Putnam, A.E., Denton, G.H., Kaplan, M.R., Barrell, D.J.A., Andersen, B.G., Kelley, S.E., Finkel, R.C., Schwartz, R. 2015. Mismatch of glacier extent and summer insolation in Southern Hemisphere mid-latitudes. Geology 43 (5), 407-410. https://doi.org/10.1130/G36477.1.

Fairman, M. 2006. Unpublished Master's thesis, The Ohio State University.

Farber, D.L., Hancock, G.S., Finkel, R.C., Rodbell, D.T. 2005. The age and extent of tropical alpine glaciation in the Cordillera Blanca, Peru. Journal of Quaternary Science 20, 759-776.

Garreaud, R.D., Vuille, M., Compagnucci, R., Marengo, J. 2009. Present-day South American climate. Palaeogeography, Palaeoclimatology, Palaeoecology 281 (3-4), 180-195. http://doi. org/10.1016/j.palaeo.2007.10.032.

Glasser, N.F., Clemmens, S., Schnabel, C., Fenton, C.R., McHargue, L. 2009. Tropical glacier fluctuations in the Cordillera Blanca, Peru between 12.5 and $7.6 \mathrm{ka}$ from cosmogenic ${ }^{10}$ Be dating. Quaternary Science Reviews 28 (27-28), 3448-3458. http://doi.org/10.1016/j. quascirev.2009.10.006.

Goehring, B.M., Muzikar, P., Lifton, N.A. 2013. An in situ ${ }^{14} \mathrm{C}-{ }^{10} \mathrm{Be}$ Bayesian isochron approach for interpreting complex glacial histories. Quaternary Geochronology 15, 61-66. http://doi. org/10.1016/j.quageo.2012.11.007.

Goehring, B.M., Schaefer, J.M., Schluechter, C., Lifton, N.A., Finkel, R.C., Jull, A.T., Akçar, N., Alley, R.B. 2011. The Rhone Glacier was smaller than today for most of the Holocene. Geology 39 (7), 679-682. https://doi.org/10.1130/G32145.1.

Goodman, A.Y., Rodbell, D.T., Seltzer, G.O., Mark, B.G. 2001. Subdivision of glacial deposits in southeastern Peru based on pedogenic development and radiometric ages. Quaternary Research 56, 31-50. https://doi.org/10.1006/qres.2001.2221.

Gregory-Wodzicki, K.M. 2000. Uplift history of the Central and Northern Andes: A review. Geological Society of America Bulletin 112 (7), 1091-1105. https://doi.org/10.1130/00167606(2000)112\&lt;1091:UHOTCA\&gt;2.0.CO;2.

Hall, S.R., Farber, D.L., Ramage, J.M., Rodbell, D.T., Finkel, R.C., Smith, J.A., Mark, B.G., Kassel, C. 2009. Geochronology of Quaternary glaciations from the tropical Cordillera Huayhuash, Peru. Quaternary Science Reviews 28 (25-26), 2991-3009. http://doi.org/10.1016/j. quascirev.2009.08.004.

Hansen, B.C.S., Rodbell, D.T. 1995. A Late-Glacial/Holocene Pollen Record from the Eastern Andes of Northern Peru. Quaternary Research 44, 216-227. https://doi.org/10.1006/ qres.1995.1066.

Hartley, A.J. 2003. Andean uplift and climate change. Journal of the Geological Society 160 (1), 7-10. https://doi.org/10.1144/0016-764902-083.

Hastenrath, S. 1985. A review of Pleistocene to Holocene glacier variations in the tropics. Zeitschrift fur Gletscherkunde und Glazialgeologie 21, 183-194.

Hastenrath, S. 2009. Past glaciation in the tropics. Quaternary Science Reviews 28 (9-10), 790798. http://doi.org/10.1016/j.quascirev.2008.12.004.

He, F., Shakun, J.D., Clark, P.U., Carlson, A.E., Liu, Z., Otto-Bliesner, B.L., Kutzbach, J.E. 2013. Northern Hemisphere forcing of Southern Hemisphere climate during the last deglaciation. Nature 494, 81-85. http://doi.org/10.1038/nature11822. 
Heine, K. 2000. Tropical South America during the Last Glacial Maximum: evidence from glacial, periglacial and fluvial records. Quaternary International 72 (1), 7-21. http://doi. org/10.1016/S1040-6182(00)00017-3.

Henderson, K.A., Thompson, L.G., Lin, P.N. 1999. Recording El Nino in ice core $\delta^{18} \mathrm{O}$ records from Nevado Huascaran, Peru. Journal of Geophyscial Research 104 (D24), 31053031065. http://doi.org/10.1029/1999JD900966.

Hillyer, R., Valencia, B.G., Bush, M.B., Silman, M.R., Steinitz-Kannan, M. 2009. A 24,700-yr paleolimnological history from the Peruvian Andes. Quaternary Research 71 (1), 71-82. http://doi.org/10.1016/j.yqres.2008.06.006.

Insel, N., Poulsen, C.J., Ehlers, T.A., Sturm, C. 2012. Response of meteoric $\delta^{18} \mathrm{O}$ to surface uplift - Implications for Cenozoic Andean Plateau growth. Earth and Planetary Science Letters 317-318, 262-272. http://doi.org/10.1016/j.eps1.2011.11.039.

Johnson, A.M. 1976. The Climate of Peru, Bolivia and Ecuador. In: W. Schwerdtfeger (Ed.), World Survey of Climatology Volume 12, Climates of Central and South America, Elsevier.

Kanner, L.C., Burns, S.J., Cheng, H., Edwards, R.L. 2012. High-Latitude Forcing of the South American Summer Monsoon During the Last Glacial. Science 335, 570-573. http://doi. org/10.1126/science.1213397.

Kaser, G., Georges, C. 1997. Changes of the equilbrium-line altitude in the tropical Cordillera Blanca, Peru, 1930-1950, and their spatial variations. Annals of Glaciology 24, 344-349. https://doi.org/10.1017/S0260305500012428.

Kaser, G., Osmaston, H. 2002. Tropical Glaciers. Cambridge University Press, Cambridge, 207 pp.

Kelly, M.A., Lowell, T.V., Applegate, P.J., Phillips, F.M., Schaefer, J.M., Smith, C.A., Kim, H., Leonard, K.C., Hudson, A.M. 2015. A locally calibrated, late glacial ${ }^{10} \mathrm{Be}$ production rate from a low-latitude, high-altitude site in the Peruvian Andes. Quaternary Geochronology 26, 70-85. http://doi.org/10.1016/j.quageo.2013.10.007.

Kelly, M.A., Lowell, T.V., Applegate, P.J., Smith, C.A., Phillips, F.M., Hudson, A.M. 2012. Late glacial fluctuations of Quelccaya Ice Cap, southeastern Peru. Geology 40 (11), 991-994. https://doi.org/10.1130/G33430.1.

Kienast, M., Kienast, S.S., Calvert, S.E., Eglinton, T.I., Mollenhauer, G., François, R., Mix, A.C. 2006. Eastern Pacific cooling and Atlantic overturning circulation during the last deglaciation. Nature 443, 846-849. http://doi.org/10.1038/nature05222.

Kull, C., Imhof, S., Grosjean, M., Zech, R., Veit, H. 2008. Late Pleistocene glaciation in the Central Andes: Temperature versus humidity control-A case study from the eastern Bolivian Andes $\left(17^{\circ} \mathrm{S}\right)$ and regional synthesis. Global and Planetary Change 60 (1-2), 148-164. http://doi.org/10.1016/j.gloplacha.2007.03.011.

La Frenierre, J., Huh, K.I., Mark, B.G. 2011. Ecuador, Peru and Bolivia. In: J. Ehlers, P.L. Gibbard, P.D. Hughes (Eds.), Quaternary Glaciations - Extent and Chronology: A Closer Look, pp. 773-802. http://doi.org/10.1016/B978-0-444-53447-7.00056-8.

Lal, D. 1991. Cosmic ray labeling of erosion surfaces: in situ nuclide production rates and erosion models. Earth and Planetary Science Letters 104 (2-4), 424. http://doi.org/10.1016/0012821X(91)90220-C.

Licciardi, J.M., Schaefer, J.M., Taggart, J.R., Lund, D.C. 2009. Holocene glacier fluctuations in the Peruvian Andes indicate northern climate linkages. Science 325 (5948), 1677-1679. https://doi.org/10.1126/science.1175010.

Machare, J., Veliz, Y., Ortlieb, L., Dumont, J.-F. 1990. A review of recent paleoclimatic studies in Peru. In: J. Rabassa, M. Salemme (Eds.), Quaternary of South America and Antarctic Peninsula 8, A.A. Balkema. Rotterdam, 157-178 pp. http://horizon.documentation.ird.fr/ exl-doc/pleins_textes/pleins_textes_7/b_fdi_51-52/010015055.pdf. 
Mark, B.G., Seltzer, G.O., Rodbell, D.T., Goodman, A.Y. 2002. Rates of deglaciation during the last glaciation and Holocene in the Cordillera Vilcanota-Quelccaya ice cap region, southeastern Peru. Quaternary Research 57 (3), 287-298. http://doi.org/10.1006/qres.2002.2320.

Mark, B.G., Harrison, S., Spessa, A., New, M., Evans, D.J.A., Helmens, K.F. 2005. Tropical snowline changes at the last glacial maximum: A global assessment. Quaternary International 138-139, 168-201. http://doi.org/10.1016/j.quaint.2005.02.012.

Mark, B.G., Seltzer, G.O. 2005. Evaluation of recent glacier recession in the Cordillera Blanca, Peru (AD 1962-1999): spatial distribution of mass loss and climatic forcing. Quaternary Science Reviews 24 (20-21), 2265-2280. http://doi.org/10.1016/j.quascirev.2005.01.003.

Maslin, M.A., Burns, S.J. 2000. Reconstruction of the Amazon Basin Effective Moisture Availability over the Past 14,000 Years. Science 290 (5500), 2285-2287. https://doi. org/10.1126/science.290.5500.2285.

Maslin, M.A., Ettwein, V.J., Wilson, K.E., Guilderson, T.P., Burns, S.J., Leng, M.J. 2011. Dynamic boundary-monsoon intensity hypothesis: evidence from the deglacial Amazon River discharge record. Quaternary Science Reviews 30 (27-28), 3823-3833. http://doi. org/10.1016/j.quascirev.2011.10.007.

Mercer, J.H. 1984. Late Cainozoic glacial variations in South America south of the equator. In: J.C. Vogel (Ed.), Late Cenozoic Paleoclimates of the Southern Hemisphere. Balkema, Rotterdam, pp. 45-58.

Mercer, J.H., Palacios, O.M. 1977. Radiocarbon dating of last glaciation in Peru. Geology 5, 600604. https://doi.org/10.1130/0091-7613(1977)5\&lt;600:RDOTLG\&gt;2.0.CO;2.

Nobre, P., Srukla, J. 1996. Variations of Sea Surface Temperature, Wind Stress, and Rainfall over the Tropical Atlantic and South America. Journal of Climate 9, 2464-2479. http://doi. org/10.1175/1520-0442(1996)009<2464:VOSSTW>2.0.CO;2.

Placzek, C., Quade, J., Patchett, P.J. 2006. Geochronology and stratigraphy of late Pleistocene lake cycles on the southern Bolivian Altiplano: Implications for causes of tropical climate change. Geological Society of America Bulletin 118, 515-532. https://doi.org/10.1130/B25770.1.

Porter, S.C. 2001. Snowline depression in the tropics during the Last Glaciation. Quaternary Science Reviews 20 (10), 1067-1091. http://doi.org/10.1016/S0277-3791(00)00178-5.

Rodbell, D.T. 1992. Late Pleistocene Equilibrium-Line Reconstructions in the Northern Peruvian Andes. Boreas 21, 43-52. http://doi.org/10.1111/j.1502-3885.1992.tb00012.x.

Rodbell, D.T. 1993a. Subdivision of late Pleistocene moraines in the Cordillera Blanca, Peru, based on rock-weathering features, soils, and radiocarbon dates. Quaternary Research 39 (2), 133-143. http://doi.org/10.1006/qres.1993.1017.

Rodbell, D.T. 1993b. The Timing of the Last Deglaciation in Cordillera Oriental, Northern Peru, based on Glacial Geology and Lake Sedimentology. Geological Society of America Bulletin 105 (7), 923-934. https://doi.org/10.1130/0016-7606(1993)105\&lt;0923:TTOTLD\&gt;2.3.CO;2.

Rodbell, D.T. 2000. The Younger Dryas: Cold, cold everywhere? Science 290 (5490), 285-286. https://doi.org/10.1126/science.290.5490.285.

Rodbell, D.T., Seltzer, G.O. 2000. Rapid ice margin fluctuations during the Younger Dryas in the tropical Andes. Quaternary Research 54 (3),328-338. http://doi.org/10.1006/qres.2000.2177.

Rodbell, D.T., Seltzer, G.O., Mark, B.G., Smith, J.A., Abbott, M.B. 2008. Clastic sediment flux to tropical Andean lakes: records of glaciation and soil erosion. Quaternary Science Reviews 27 (15-16), 1612-1626. http://doi.org/10.1016/j.quascirev.2008.06.004.

Rodbell, D.T., Smith, J.A., Mark, B.G. 2009. Glaciation in the Andes during the Lateglacial and Holocene. Quaternary Science Reviews 28 (21-22), 2165-2212. http://doi.org/10.1016/j. quascirev.2009.03.012.

Seltzer, G., Rodbell, D., Burns, S. 2000. Isotopic evidence for late Quaternary climatic change in tropical South America. Geology 28, 35-38. https://doi.org/10.1130/00917613(2000)28\&lt; 35:IEFLQC\&gt;2.0.CO;2. 
Seltzer, G.O. 1990. Recent glacial history and paleoclimate of the Peruvian-Bolivian Andes. Quaternary Science Reviews 9 (2-3), 137-152. http://doi.org/10.1016/0277-3791(90)90015-3.

Seltzer, G.O. 1992. Late Quaternary Glaciation of the Cordillera Real, Bolivia. Journal of Quaternary Science 7 (2), 87-98. http://doi.org/10.1002/jqs.3390070202.

Seltzer, G.O. 1993. Late-Quaternary Glaciation as a Proxy for Climate-Change in the Central Andes. Mountain Research and Development 13 (2), 129-138. http://doi.org/10.2307/3673630.

Seltzer, G.O. 1994. A Lacustrine Record of Late Pleistocene Climatic-Change in the Subtropical Andes. Boreas 23 (2), 105-111. http://doi.org/10.1111/j.1502-3885.1994.tb00591.x.

Seltzer, G.O., Rodbell, D.T., Abbott, M. 1995. Andean glacial lakes and climate variability since the Last Glacial Maximum. Bulletin de l'Institut Français d'Études Andines 24, 539-549. http://www.pitt.edu/ mabbott1/climate/mark/Abstracts/Pubs/Seltzeretal95.pdf.

Seltzer, G.O., Rodbell, D.T., Baker, P.A., Fritz, S.C., Tapia, P.M., Rowe, H.D., Dunbar, R.B. 2002. Early warming of tropical South America at the Last Glacial- interglacial transition. Science 296 (5573), 1685-1686. https://doi.org/10.1126/science.1070136.

Shakun, J.D., Clark, P.U., He, F., Lifton, N.A., Liu, Z., Otto-Bliesner, B.L. 2015a. Regional and global forcing of glacier retreat during the last deglaciation. Nature Communications 6, 8059 . http://doi.org/10.1038/ncomms9059.

Shakun, J.D., Clark, P.U., Marcott, S.A., Brook, E.J., Lifton, N.A., Caffee, M., Shakun, W.R. 2015b. Cosmogenic dating of Late Pleistocene glaciation, southern tropical Andes, Peru. Journal of Quaternary Science 30 (8), 841-847. http://doi.org/10.1002/jqs.2822.

Smith, C.A., Lowell, T.V., Caffee, M.W. 2009. Lateglacial and Holocene cosmogenic surface exposure age glacial chronology and geomorphological evidence for the presence of coldbased glaciers at Nevado Sajama, Bolivia. Journal of Quaternary Science 24 (4), 360-372. http://doi.org/10.1002/jqs.1239.

Smith, C.A., Lowell, T.V., Owen, L.A., Caffee, M.W. 2011. Late Quaternary glacial chronology on Nevado Illimani, Bolivia, and the implications for paleoclimatic reconstructions across the Andes. Quaternary Research 75 (1), 1-10. http://doi.org/10.1016/j.yqres.2010.07.001.

Smith, J.A., Mark, B.G., Rodbell, D.T. 2008. The timing and magnitude of mountain glaciation in the tropical Andes. Journal of Quaternary Science 23 (6-7), 609-634. http://doi.org/10.1002/jqs.1224.

Smith, J.A., Rodbell, D.T. 2010. Cross-cutting moraines reveal evidence for North Atlantic influence on glaciers in the tropical Andes. Journal of Quaternary Science 25 (3), 243-248. http://doi.org/10.1002/jqs.1393.

Smith, J.A., Seltzer, G.O., Farber, D.L., Rodbell, D.T., Finkel, R.C. 2005. Early Local Last Glacial Maximum in the Tropical Andes. Science 308 (5722), 678-681.https://doi.org/10.1126/ science.1107075.

Stansell, N.D., Licciardi, J.M., Rodbell, D., Mark, B.G. 2017. Late Glacial and Holocene glacier fluctuations in the Cordillera Blanca, Peruvian Andes. Geophysical Research Letters 44 (9). 4176-4185. http://doi.org/10.1002/2016GL072408.

Stansell, N.D., Rodbell, D.T., Abbott, M.B., Mark, B.G. 2013. Proglacial lake sediment records of Holocene climate changes in the Western Cordillera of Peru. Quaternary Science Reviews 70 , 1-14. http://doi.org/10.1016/j.quascirev.2013.03.003.

Stansell, N.D., Rodbell, D.T., Licciardi, J.M., Sedlak, C.M., Schweinsberg, A.D., Huss, E.G., Delgado, G.M., Zimmerman, S.H., Finkel, R.C. 2015. Late Glacial and Holocene glacier fluctuations at Nevado Huaguruncho in the Eastern Cordillera of the Peruvian Andes. Geology 43 (8), 747-750. http://doi.org/10.1130/G36735.1.

Stone, J.O. 2000. Air pressure and cosmogenic isotope production. Journal of Geophysical Research 105 (B10), 23753-23759. http://doi.org/10.1029/2000JB900181.

Stroup, J.S., Kelly, M.A., Lowell, T.V., Applegate, P.J., Howley, J.A. 2014. Late Holocene fluctuations of Qori Kalis outlet glacier, Quelccaya Ice Cap, Peruvian Andes. Geology 42 (49), 347-350. http://doi.org/10.1130/G35245.1. 
Thompson, L.G., Davis, M.E., Mosley-Thompson,E., Sowers, T.A., Henderson, K.A., Zagorodnov, V.S., Lin, P.N., Mikhalenko, V.N., Campen, R.K., Bolzan, J.F., Cole-Dai, J., Francou, B. 1998. A 25,000-year tropical climate history from Bolivian ice cores. Science 282 (5395), 1858-1864. https://doi.org/10.1126/science.282.5395.1858.

Thompson, L.G., Mosley-Thompson, E., Brecher, H., Davis, M., León, B., Les, D., Lin, P.N., Mashiotta, T., Mountain, K. 2006. Abrupt tropical climate change: Past and present. Proceedings of the National Academy of Sciences of the United States of America 103 (28), 10536-10543. http://doi.org/10.1073/pnas.0603900103.

Thompson, L.G., Mosley-Thompson, E., Davis, M.E., Lin, P.N., Henderson, K.A., Cole-Dai, J., Bolzan, J.F. 1995. Late glacial stage and Holocene tropical ice core records from Huascaran, Peru. AGU 1995 spring meeting Eos, Transactions, American Geophysical Union 76, 176.

Vuille, M., Bradley, R.S., Keimig, F. 2000. Interannual climate variability in the Central Andes and its relation to tropical Pacific and Atlantic forcing. Journal of Geophyscial Research 105 (D10), 12447-12460. http://doi.org/10.1029/2000JD900134.

Vuille, M., Burns, S.J., Taylor, B.L., Cruz, F.W., Bird, B.W., Abbott, M.B., Kanner, L.C., Cheng, H., Novello, V.F. 2012. A review of the South America monsoon history as recorded in stable isotope proxies over the past two millennia. Climate of the Past 8, 1309-1321. http://doi. org/10.5194/cp-8-1309-2012.

Vuille, M., Francou, B., Wagnon, P., Juen, I., Kaser, G., Mark, B.G., Bradley, R.S. 2008a. Climate change and tropical Andean glaciers: Past, present and future. Earth-Science Reviews 89, 7996. http://doi.org/10.1016/j.escirev.2008.04.002.

Vuille, M., Kaser, G., Juen, I. 2008. Glacier mass balance variability in the Cordillera Blanca, Peru and its relationship with climate and the large-scale circulation. Global and Planetary Change 62 (1-2), 14-28. http://doi.org/10.1016/j.gloplacha.2007.11.003.

Vuille, M., Werner, M. 2005. Stable isotopes in precipitation recording South American summer monsoon and ENSO variability: observations and model results. Climate Dynamics 25 (4), 401-413. http://doi.org/10.1007/s00382-005-0049-9.

Weng, C.Y., Bush, M.B., Curtis, J.H., Kolata, A.L., Dillehay, T.D., Binford, M.W. 2006. Deglaciation and Holocene climate change in the western Peruvian Andes. Quaternary Research 66 (1), 87-96. http://doi.org/10.1016/j.yqres.2006.01.004.

Wright, H.E. 1983. Late-Pleistocene glaciation and climate around the Junin Plain Central Peruvian highlands. Geografiska Annaler 65A (1-2), 35-43. http://doi.org/10.2307/520719.

Wright, H.E. 1984. Late Glacial and late Holocene moraines in the Cerros Cuchpanga, Central Peru. Quaternary Research 21 (3), 275-285. http://doi.org/10.1016/0033-5894(84)90068-1.

Zech,J.,Zech,R.,May,J.-H., Kubik,P.W., Veit,H.2010.Lateglacial and early Holocene glaciation in the tropical Andes caused by La Niña-like conditions. Palaeogeography, Palaeoclimatology, Palaeoecology 293 (1-2), 248-254. http://doi.org/10.1016/j.palaeo.2010.05.026.

Zech, R., Kull, C., Kubik, P.W., Veit, H. 2007. LGM and Late Glacial glacier advances in the Cordillera Real and Cochabamba (Bolivia) deduced from ${ }^{10} \mathrm{Be}$ surface exposure dating. Climate of the Past Discussions 3, 839-869. http://doi.org/10.5194/cp-3-623-2007.

Zech, R., May, J.-H., Kull, C., Ilgner, J., Kubik, P.W., Veit, H. 2008. Timing of the late Quaternary glaciation in the Andes from 15 to $40^{\circ}$ S. Journal of Quaternary Science 23 (6-7), 635-647. http://doi.org/10.1002/jqs.1200.

Zech, R., Smith, J.A., Kaplan, M. 2009. Chronologies of the Last Glacial Maximum and its Termination in the Andes ( 10-55S) Based on Surface Exposure Dating. In: F. Vimeux, F. Sylvestre, M. Khodri (Eds.), Past Climate Variability in South America and Surrounding Regions, Developments in Paleoenvironmental Research 14, Springer, pp, 61-87. http://doi. org/10.1007/978-90-481-2672-9_3.

Zhou, J.,Lau, K.-M. 1998. Does a Monsoon Climate Exist over South America? Journal of Climate 11, 1020-1040. http://doi.org/10.1175/1520-0442(1998)011<1020:DAMCEO>2.0.CO;2. 